University of Nebraska - Lincoln

DigitalCommons@University of Nebraska - Lincoln

\title{
Observational Analysis of the 27 May 1997 Central Texas Tornadic Event. Part I: Prestorm Environment and Storm Maintenance/Propagation
}

Adam L. Houston

Robert B. Wilhelmson

Follow this and additional works at: https://digitalcommons.unl.edu/geosciencefacpub

Part of the Earth Sciences Commons

This Article is brought to you for free and open access by the Earth and Atmospheric Sciences, Department of at DigitalCommons@University of Nebraska - Lincoln. It has been accepted for inclusion in Papers in the Earth and Atmospheric Sciences by an authorized administrator of DigitalCommons@University of Nebraska - Lincoln. 


\title{
Observational Analysis of the 27 May 1997 Central Texas Tornadic Event. Part I: Prestorm Environment and Storm Maintenance/Propagation
}

\author{
ADAM L. HOUSTON* \\ Department of Earth and Atmospheric Sciences, Purdue University, West Lafayette, Indiana \\ ROBERT B. WiLHELMSON \\ National Center for Supercomputing Applications, and Department of Atmospheric Sciences, \\ University of Illinois at Urbana-Champaign, Urbana, Illinois
}

(Manuscript received 8 August 2005, in final form 23 May 2006)

\begin{abstract}
A detailed analysis of the 27 May 1997 central Texas tornadic storm complex is undertaken in an attempt to document the prestorm environment and identify the roles played by preexisting boundaries on storm maintenance/propagation and rotation. Analysis is carried out using a broad suite of synoptic and subsynoptic data but focuses on the level-II and -III Weather Surveillance Radar-1988 Doppler (WSR-88D) data from three Texas radars. The 27 May 1997 event was characterized by a back-building (propagation against the mean flow) storm complex that produced at least 12 tornadoes including the F5 Jarrell, Texas, tornado. Furthermore, five of the eight longest-lived cells during the analysis period are shown to contain midlevel mesocyclones. However, one-dimensional metrics calculated using representative vertical profiles of state variables reveal that, despite the extreme values of CAPE in place $\left(>6500 \mathrm{~J} \mathrm{~kg}^{-1}\right)$, the (1D) environment associated with this event is best classified as only marginally favorable for supercells and unfavorable for significant, supercellular tornadoes. Furthermore, the observed wind shear values are shown to be more in line with the vertical shear values typically associated with nonsevere back-building storms. Examples of propagation controlled by quasi-continuous maintenance of a single cell as well as successive discrete cell redevelopment are found. In all situations, two preexisting boundaries in place during this event (a cold front and a dryline) are found to have been necessary for the maintenance/propagation of the storm complex. Specifically, it is argued that the "zippering" of the cold front and dryline (the collision of the dryline and cold front that allowed the cold front to overtake the dryline and penetrate into the most unstable air to the east) was essential for the back-building of the storm complex in this event since it resulted in new cell development at points farther south. While midlevel mesocyclones were present in five of the eight longest-lived and well-sampled cells, analysis of the relationship between observed cell motion, expected cell motion, expected supercellular deviation, and boundary motion for the longest-lived and well-sampled cells reveals little evidence that deviate motions generated through supercellular dynamics governed cell motions. Instead, it is shown that boundary motions largely controlled the propagation of individual cells.
\end{abstract}

\section{Introduction}

The central Texas storm complex of 27 May 1997 warrants examination in part simply because of its se-

\footnotetext{
* Current affiliation: Department of Geosciences, University of Nebraska at Lincoln, Lincoln, Nebraska.
}

Corresponding author address: Dr. Adam L. Houston, Department of Geosciences, University of Nebraska at Lincoln, 214 Bessey Hall, Lincoln, NE 68588.

E-mail: ahouston@unl.edu

DOI: 10.1175/MWR3300.1

(C) 2007 American Meteorological Society verity: the complex produced at least 12 tornadoes including three rated $\mathrm{F} 3$, one rated $\mathrm{F} 4$, and one rated $\mathrm{F} 5$ (the Jarrell, Texas, tornado; NCDC 1997). However, several specific questions have also emerged from this case. One series of questions deals with the relationship of this environment to typical tornadic supercell environments. It will be shown that the majority of the longest-lived convective cells observed during this event were supercellular. Additionally, six of the surveyed tornadoes reported during this event were significant ( $>$ F2 intensity). But was this environment consistent with other supercell environments? Did it resemble environments that typically support significant 
tornadoes? Answering these questions is not simply an academic exercise. If discrepancies are found between the environment of this case and typical tornadic supercell environments, explaining the sources of these discrepancies may assist the refinement of methods used for supercell and tornado forecasting.

Another question relates to the unusual translation/ propagation of the 27 May 1997 storm complex and the dependence of this motion on preexisting boundaries. The storm complex was found to travel against the mean environmental wind (a process referred to as back building; Bluestein and Jain 1985) along a dryline near its intersection with a cold front and the storm's gust front. While an implicit dependence of this motion on the preexisting airmass boundaries may seem obvious, the nature of this dependence has not been examined.

This examination of the 27 May 1997 central Texas event will be presented in several articles but can be categorized into two main components: 1) observational analysis of the event and 2) complementary numerical simulations conducted to test hypotheses and open questions that emerge from the observational analysis. Results from the observational component will be presented in two articles. In this first article (Part I in the series) the prestorm environment of the event is described along with results from an examination of the role of boundaries on storm maintenance and propagation. The second article of the observational component (Houston and Wilhelmson 2007, Part II) documents the results from an examination of observed mesocyclones and tornadoes.

This article proceeds with a description of the environment associated with the 27 May 1997 event in which the environment is characterized with respect to canonical supercellular and significant tornadic environments. This section also describes the preexisting airmass boundaries that were in place. In section 3 results are presented from our analysis of storm propagation and maintenance, with a focus on the role that was played by preexisting and storm-generated boundaries. Section 4 includes a discussion of results, focusing on the mechanisms responsible for the observed backbuilding propagation/maintenance. A summary of findings follows in section 5 .

\section{27 May 1997 prestorm environment}

a. Vertical profiles of temperature, moisture, and momentum

A composite sounding constructed by L. J. Wicker et al. (1997, unpublished manuscript) based on a Mobile
Cross Long-Range Navigation (LORAN) Atmospheric Sounding System (MCLASS) sounding released at 1945 UTC 5 mi north-northeast of Calvert, Texas, ${ }^{1}$ as part of the Texas A\&M Convection and Lightning experiment (TEXACAL; Biggerstaff et al. 1997) revealed a CAPE of approximately $4900 \mathrm{~J} \mathrm{~kg}^{-1}$ and a lifted index (LI) of approximately -8 (Fig. 1a). (A composite sounding is used because the Calvert sounding prematurely terminated.) The upper levels (above approximately $6200 \mathrm{~m}$ ) of this sounding were drawn from the Rapid Update Cycle (RUC) 2100 UTC data near Temple, Texas, approximately $66 \mathrm{~km}$ west-northwest of Calvert. RUC data near Temple were used instead of data near Calvert because Temple was closer to the location of storm initiation. Although the CAPE of this sounding was large, the surface temperature and mixing ratio at Calvert were unrepresentative of the low-level air mass nearer to the storm complex. Modification of the composite Calvert sounding to reflect the warmer and moister lower levels near the location of the incipient convection yielded a CAPE of greater than $6500 \mathrm{~J} \mathrm{~kg}^{-1}$ and an LI of approximately -11 (Fig. 1b). These values were found to be consistent with the 1900 UTC estimation of LI from the Geostationary Operational Environmental Satellite (GOES-8) sounder data (Fig. 2). It should be noted that sounder calibration errors on this day may have resulted in the overestimation of LI magnitudes (NOAA 1998, their appendix B). In fact, it is clear from Fig. 2 that the magnitude of the satelliteestimated LI near the location of the Calvert sounding (denoted with a square) was 3-4 K too large. Nevertheless, including a $3-\mathrm{K}$ error in the LI estimation still yielded LI values that were 1) larger nearer to the storm complex and 2) indisputably large.

Though unusually large, the high CAPE observed over central Texas on 27 May 1997 had been in place over much of north and central Texas for several days. The Fort Worth, Texas, soundings from 0000 UTC on 26 and 27 May (not shown) revealed CAPE values of 4700 and $6700 \mathrm{~J} \mathrm{~kg}^{-1}$, respectively. These unusually high values were partly the result of multiple days of moisture advection into Texas off of the Gulf of Mexico. Furthermore, central Texas remained free of frontal penetrations in the $36 \mathrm{~h}$ preceding the event.

Only modest increases in the midtropospheric wind speeds were observed over central Texas on 27 May. Note from Fig. 3 that the wind speeds measured by the central Texas Weather Surveillance Radar-1988 Doppler (WSR-88D) (KGRK) at several levels in the 10 000-16 000-ft (3-5 km) layer increased between ap-

\footnotetext{
${ }^{1}$ Calvert is located $91 \mathrm{~km}$ east-northeast of Jarrell.
} 


\section{a) Calvert Sounding}

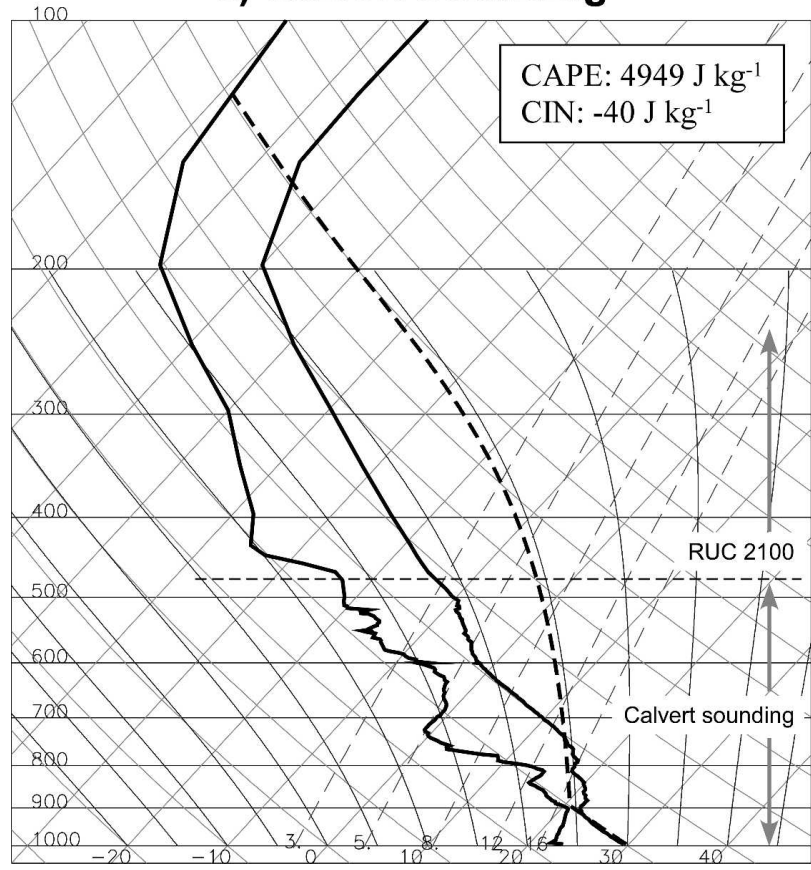

b) Modified Calvert Sounding

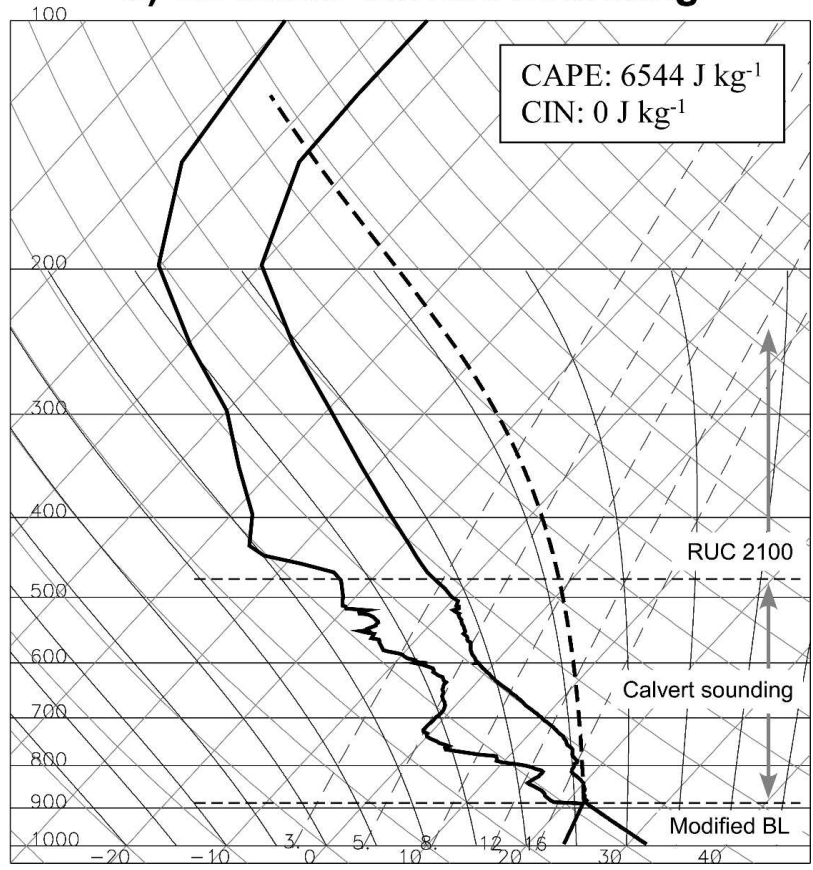

FIG. 1. Composite thermodynamic profiles at Calvert, TX. (a) Profile constructed using the original Calvert sounding in the lowest $6200 \mathrm{~m}$ and the RUC 2100 UTC analysis at Temple, TX, above $6200 \mathrm{~m}$. (b) Profile constructed using the approximate 2100 UTC boundary layer (BL) at Temple, TX, based on the TPL surface temperature and moisture observation, along with the original composite Calvert profile above $1000 \mathrm{~m}$.

proximately 1700 and 2000 UTC. This increase is also reflected in the subsynoptic data from the Eta Data Assimilation System (EDAS) ${ }^{2}$ illustrated in Figs. 4a,b. However, comparison of the EDAS wind speeds to the wind speeds observed by the KGRK radar (located at the position of the small black circle in Fig. 4) and to the wind speeds measured by the Calvert sounding (located at the position of the small black square) reveals that the EDAS-estimated wind speeds were too large. Upper-tropospheric winds were consistently out of the west-southwest at less than $20 \mathrm{~m} \mathrm{~s}^{-1}$ throughout the day (Fig. 4c).

It should be noted that at 2000 UTC the central Texas storm complex had been ongoing for $1.5 \mathrm{~h}$ and was located approximately $40 \mathrm{~km}$ to the northnorthwest of the KGRK radar. The modification of the flow near ongoing deep convection has been noted by Beebe (1958) and Weisman et al. (1998). Thus, the possibility of far-field modification of the flow by the storm must at least be acknowledged.

To characterize the environment over central Texas for this event, several wind profiles were constructed

\footnotetext{
${ }^{2}$ EDAS data are generated through synthesis of successive 3-h Eta model forecasts and optimum interpolation analyses of wind profiler, WSR-88D, and aircraft data.
}

using the available observations. The first profile illustrated in Fig. 5 included the Calvert sounding observations for the winds in the layer between 1380 and $6200 \mathrm{~m}$ AGL, the RUC 2100 UTC model initialization for the winds above $6200 \mathrm{~m}$, and, because the winds in the lowest $1380 \mathrm{~m}$ were not sampled by the MCLASS

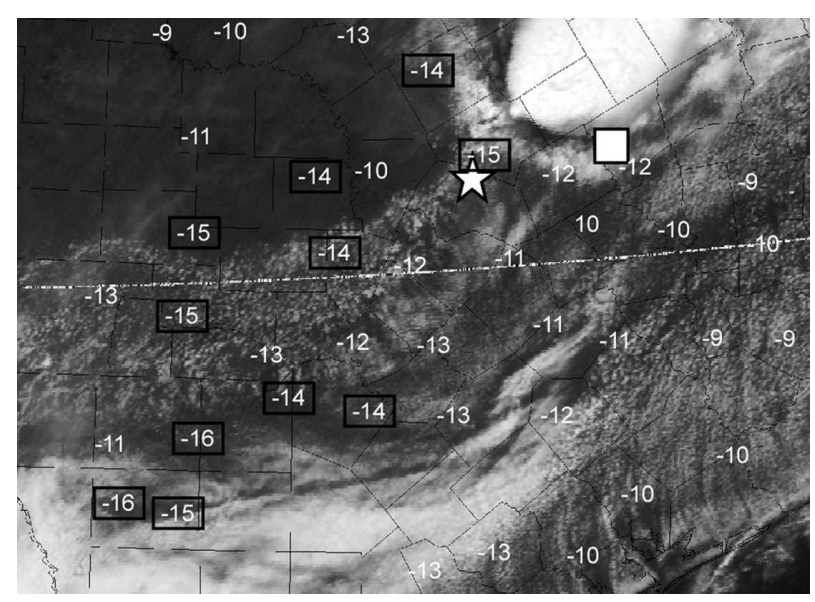

FIG. 2. The LI estimation from the GOES-8 sounder at 1900 UTC along with the 1900 UTC image from the GOES-9 visible channel. Values of $\mathrm{LI} \leq-14 \mathrm{~K}$ are framed by black boxes. The location of Jarrell is indicated with a star and the location of Calvert is indicated with a square. 


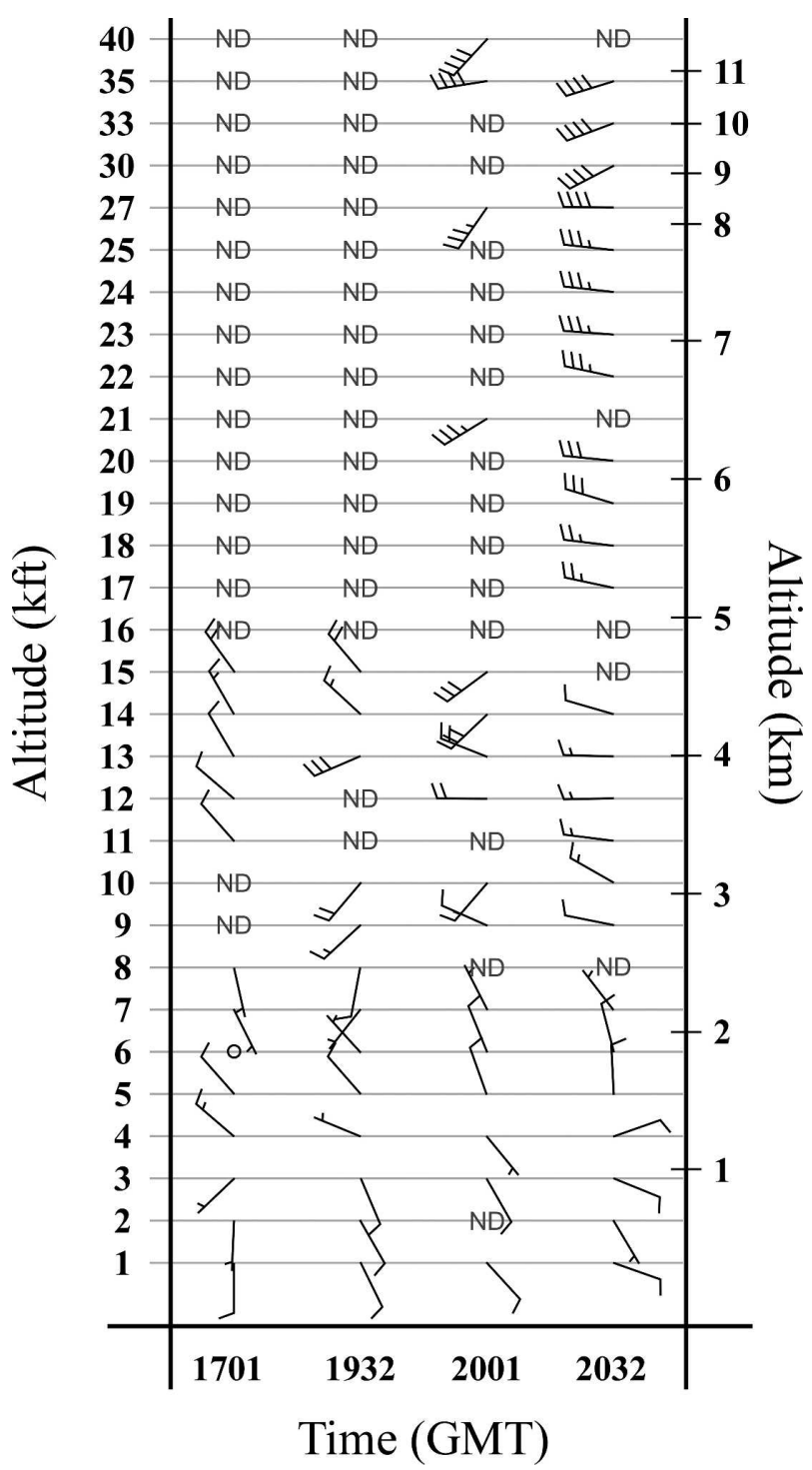

FIG. 3. Vertical wind profile from the KGRK WSR-88D for four selected times. Half barbs are $2.5 \mathrm{~m} \mathrm{~s}^{-1}$ and full barbs are $5 \mathrm{~m} \mathrm{~s}^{-1}$. "ND" indicates that no data were available.

sounding, the linearly interpolated winds between the observed surface winds near the storm complex and the observed winds at $1380 \mathrm{~m}$. The second profile, illustrated in Fig. 6, was constructed using the KGRK observations at 1932 UTC for the winds in the $0-5500-\mathrm{m}$ layer and the 2001 UTC KGRK observations for the winds above $6200 \mathrm{~m}$ (a linear interpolation was used for the intervening layer). The third profile, illustrated in Fig. 7, was constructed using the KGRK wind observations from 2001 UTC.

\section{b. Expected thunderstorm type}

The purpose of this section is to evaluate the type of thunderstorm that should have been supported in this environment without preexisting boundaries by considering parameters derived from the vertical profiles of temperature, moisture, and wind. These values will then be compared to their climatological distributions for nonsupercells and supercells. The Thompson et al. (2003, hereafter referred to as T03) climatology will be used for this comparison. The findings of T03 are similar in many regards to the climatology synthesized by Rasmussen and Blanchard (1998) and Rasmussen (2003) but preference was given to the T03 study because of its completeness ( $3 \mathrm{yr}$ of data were considered instead of $1 \mathrm{yr}$ ), specificity (T03 further subdivided the supercell classification into categories based on tornado damage; this advantage will be exploited in section 2c), and robustness (the Rasmussen and Blanchard strategy utilized proxies for supercell versus nonsupercell classification, whereas the T03 classification used the presence and persistence of a mesocyclone).

T03 found that the best parameters for discriminating between supercell and nonsupercell environments were as follows (listed in no particular order).

- 0-6-km vertical shear magnitude:

$$
\Delta V_{0-6}=\left|\mathbf{V}_{6}-\mathbf{V}_{0}\right| \text {, }
$$

where $\mathbf{V}_{6}\left(\mathbf{V}_{0}\right)$ is the wind velocity at $6 \mathrm{~km}$ (the surface).

- 0-1-km storm-relative helicity:

$\mathrm{SRH}_{0-1}=\int_{0}^{1000}\left[(\partial u / \partial z)\left(v-V_{s}\right)-(\partial v / \partial z)\left(u-U_{s}\right)\right] d z$,

where $U_{s}$ and $V_{s}$ are the components of storm motion; Davies-Jones et al. (1990).

- 0-3-km storm-relative helicity:

$$
\mathrm{SRH}_{0-3}=\int_{0}^{3000}\left[\frac{\partial u}{\partial z}\left(v-V_{s}\right)-\frac{\partial v}{\partial z}\left(u-U_{s}\right)\right] d z .
$$

- 0-1-km energy-helicity index:

$$
\mathrm{EHI}_{0-1}=\left(\mathrm{CAPE} \cdot \mathrm{SRH}_{0-1} / 1.6 \times 10^{5}\right) \text {; }
$$

Hart and Korotky (1991); Rasmussen (2003).

- Supercell composite parameter:

$$
\mathrm{SCP}=\left(\mathrm{MUCAPE} \cdot \mathrm{SRH}_{0-3} \cdot \mathrm{BRi}_{\text {shear }} / 4 \times 10^{6}\right),
$$

where MUCAPE is the CAPE computed using the "most unstable" parcel in the lowest $300 \mathrm{mb}$ of the sounding (identical to CAPE for this environment) and $\mathrm{BRi}_{\text {shear }}$ is the bulk Richardson number shear and is equal to $0.5\left|\overline{\mathbf{V}}_{0-6}-\overline{\mathbf{V}}_{0-0.5}\right|^{2}$, where $\overline{\mathbf{V}}_{0-6}\left(\overline{\mathbf{V}}_{\mathrm{BL}}\right)$ is the mean wind in the lowest $6 \mathrm{~km}(0.5 \mathrm{~km})$; T03.

Table 1 lists the values of the first three (noncomposite) parameters above, along with the mixed-layer CAPE (MLCAPE) and the lifting condensation level 
a) $700 \mathrm{mb} 1800$

$700 \mathrm{mb} 2100$

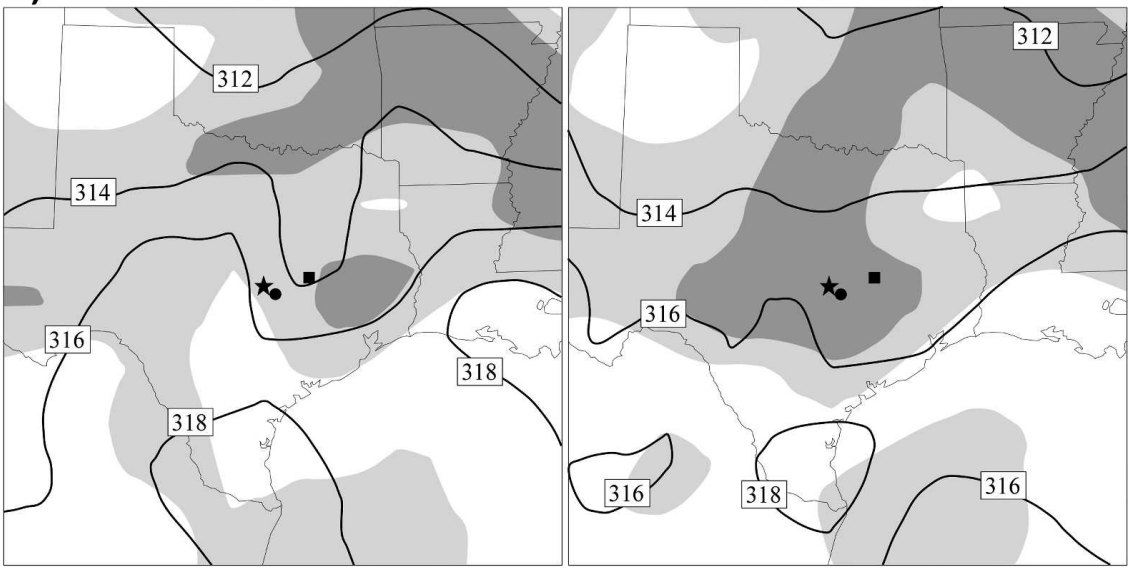

b)

$500 \mathrm{mb} 1800$

$500 \mathrm{mb} 2100$

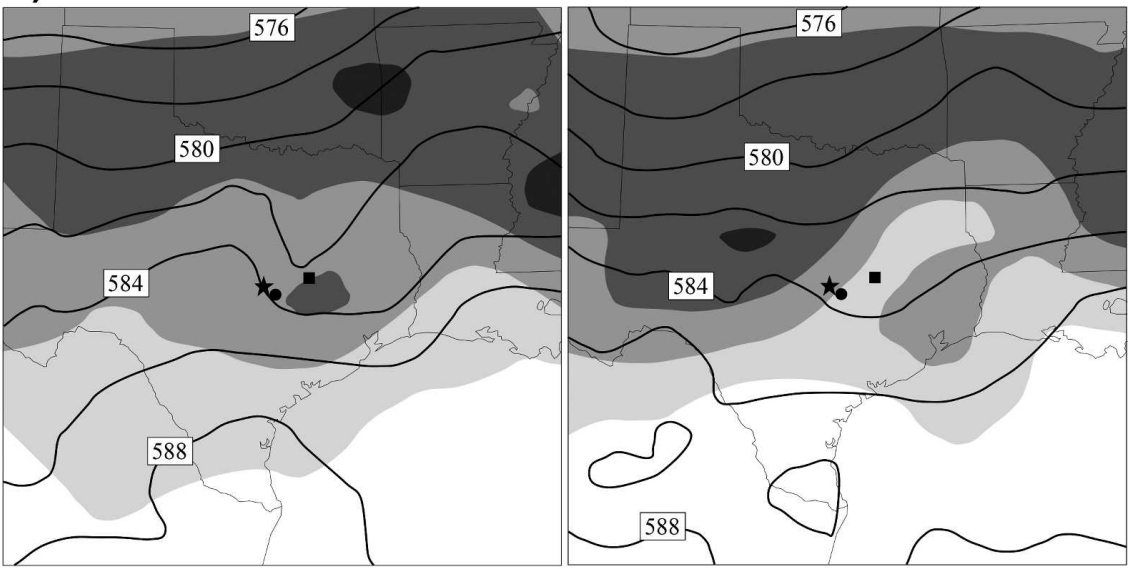

c)

$200 \mathrm{mb} 1800$

200mb 2100
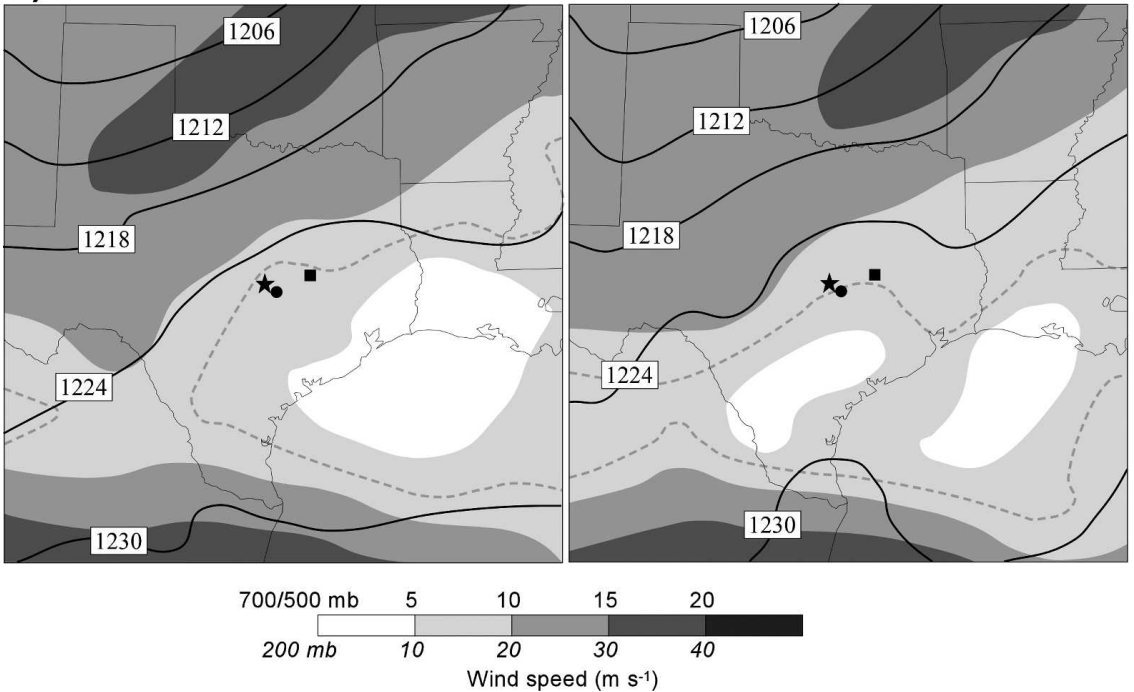

FIG. 4. EDAS wind and height data for 1800 and 2100 UTC 27 May 1997. Data from (a) 700, (b) 500 , and (c) $200 \mathrm{mb}$, respectively. Isotachs are shaded in increments of $5 \mathrm{~m} \mathrm{~s}^{-1}$ for (a), (b) and in increments of $10 \mathrm{~m} \mathrm{~s}^{-1}$ for (c). The broken gray curve in (c) represents the $15 \mathrm{~m} \mathrm{~s}^{-1}$ isotach. Thick curves represent the geopotential heights and are contoured every $20 \mathrm{~m}$ in (a), (b) and every $60 \mathrm{~m}$ in (c) (labels are in dam). The position of the star, circle, and square indicates the location of Jarrell, the KGRK radar, and Calvert, respectively. (Data are courtesy of NOAA/Air Resources Laboratory.) 


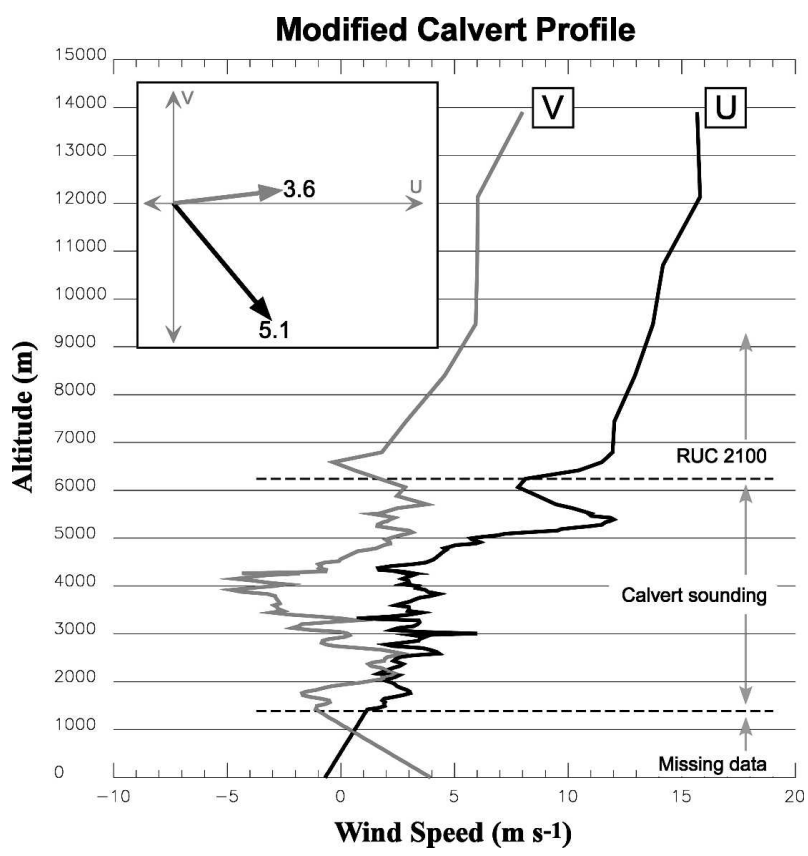

FIG. 5. Profiles of the $u$ (black curve) and $v$ (gray curve) wind components for the modified Calvert sounding. Inset illustrates the magnitude and directions of the unweighted mean $0-6-\mathrm{km}$ wind (gray arrow) and supercellular storm motion based on the Bunkers (Bunkers et al. 2000) method (black arrow), computed from the raw observations.

(LCL), corresponding to each of the wind profiles used to characterize this event. Table 2 lists the remaining (composite) parameters. The values of the stormrelative helicity (SRH) and, by extension, the energyhelicity index (EHI) and the supercell composite parameter (SCP) are highly sensitive to the predetermined cell motion. While storm motion was consistently toward the southwest in this case, little consistency could be found in the cell motions (Fig. 8). The distinction between storm and cell here follows the classification scheme of Browning (1977) wherein a storm is the envelope of individual cells. (The strategy used for cell identification and tracking will be discussed in section 3a.) Thus, to account for this variability, the cell motions for all of the longest-lived cells were used in the calculations of SRH, EHI, and SCP. ${ }^{3}$ The names of

\footnotetext{
${ }^{3}$ The theoretical basis for SRH assumes that storm motion is identical to cell motion. When the cell and storm motions are different, it is the peak updrafts (i.e., the cells) where the largest vertical vorticity is generated through the tilting of vortex lines. Thus, it is with the cells that the notion of streamwise horizontal vorticity is most relevant and therefore cell motion should be considered when calculating SRH. The climatology of Thompson et al. (2003) used the Bunkers method (Bunkers et al. 2000) for estimating storm motion. It is unclear if the predicted storm motions used by Thompson et al. differed from the observed cell motions.
}

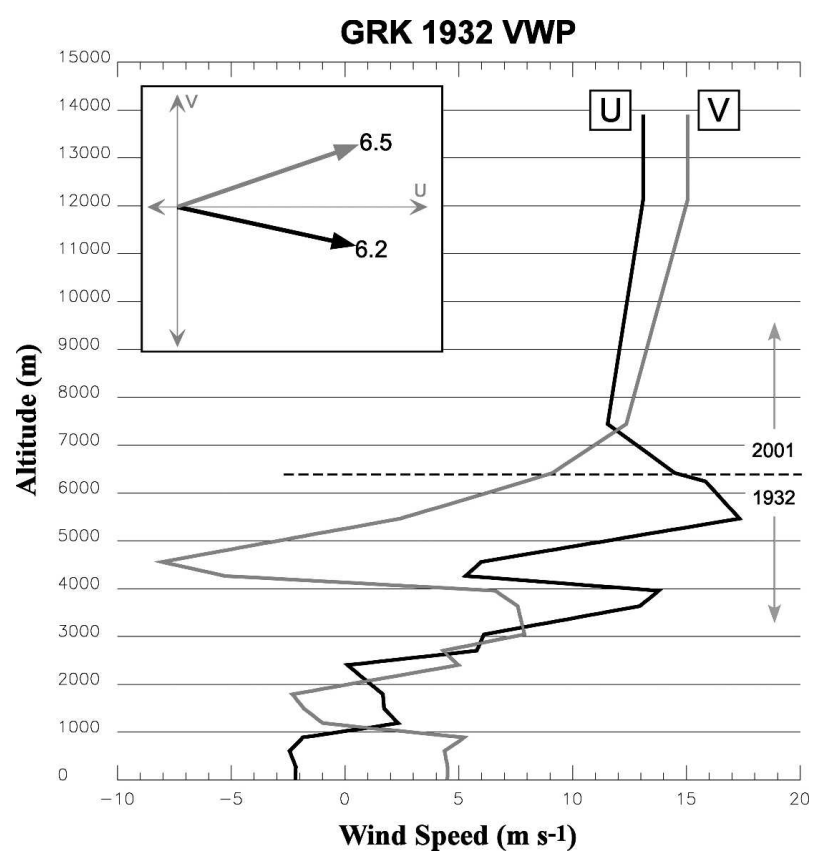

FIG. 6. Same as in Fig. 5 but for the vertical wind profile (VWP) from the KGRK radar at 1932 UTC.

cells used appear in the second columns of Tables 1 and 2 (the numeric portion of each cell name corresponds to the time of initiation).

The results of $\mathrm{T} 03$ along with the corresponding values from the three soundings described above are illustrated in Figs. 9-14. The MLCAPE comparison appearing in Fig. 9 is included here not because of its capability in discriminating between supercells and nonsupercells (note the significant overlap between the 25th-75th percentile portions of each distribution) but to illustrate that the CAPE associated with the event was significantly larger than the 90th percentile values for all distributions. The uniqueness of this event by this measure alone challenges the applicability of the T03 results to this case. Does the extreme thermal instability released during this event produce a thunderstorm type whose relationship to the parameters listed above differs markedly from the relationships captured in the distributions of $\mathrm{T} 03 ?^{4}$ In lieu of a similar climatology of extreme CAPE events, the T03 must suffice.

\footnotetext{
${ }^{4}$ As noted by a reviewer, extreme CAPE may have a profound effect on the near-storm wind field and 1D metrics computed in this modified wind field might be representative of supercell environments when the unmodified wind field is not. Such speculation is not without merit. However, the sensitivity of near-storm wind field modification to CAPE has not been systematically examined. Moreover, such near-storm observations were not available for this analysis. It is unlikely that such near-storm observations would be available to the operational forecaster either.
} 


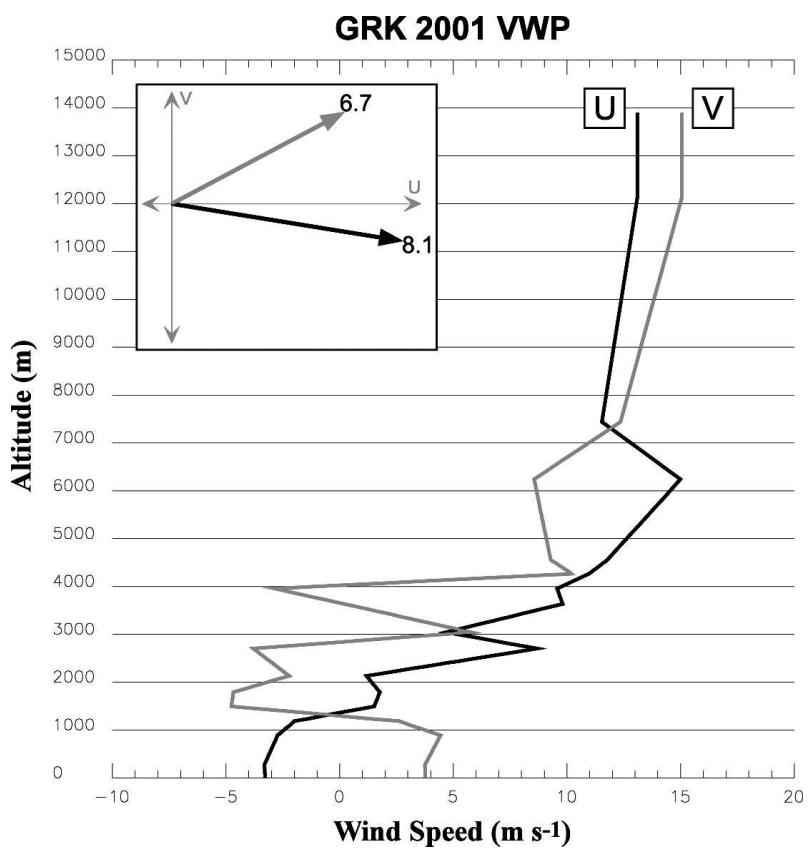

FIG. 7. Same as in Fig. 5 but for the VWP from the KGRK radar at 2001 UTC.

Based on the 0-1- and 0-3-km SRH values computed for all soundings and all cell motions of this event (Figs. 10 and 11), supercells would be unlikely. Not only do all of the values fall below the 25th percentile for all su-

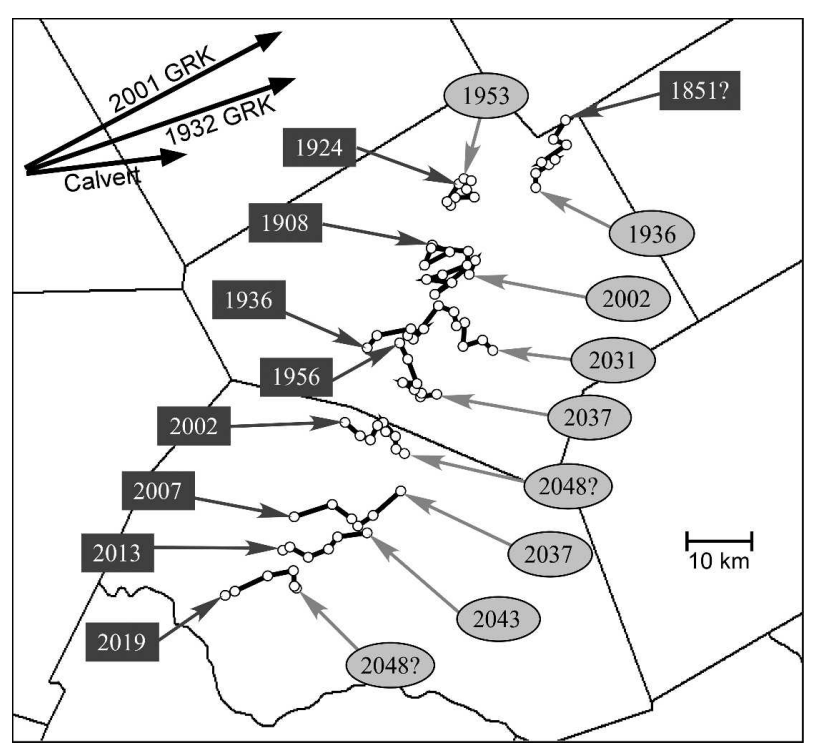

FIG. 8. Tracks of the longest-lived cells. Beginning times appear within the boxes while ending times appear within the ovals. Question marks indicate that the actual beginning or ending times likely fell outside of the analysis time interval. The white circles along each track designate the position at specific times. The black arrows in the top-left corner represent the $0-6-\mathrm{km}$ mean wind vectors from the three wind profiles illustrated in Figs. 5-7.
TABLE 1. Values for noncomposite metrics used to discriminate 1) supercell from nonsupercell environments and 2) nontornadic from significantly tornadic supercells. The wind profiles for the Calvert, KGRK 1932 UTC, and KGRK 2001 UTC wind profiles appear in Figs. 5-7. The MLCAPE values are based on the modified Calvert sounding (Fig. 1b). Multiple values appear for SRH to account for variations in the motions of observed cells. The motions used correspond to the longest-lived cells identified between 1851 and 2048 UTC (the numeric portion of each cell name corresponds to the time of initiation). Cell 1936A is further partitioned into two components corresponding to two segments of vastly different but temporally coherent motions (see Fig. 8). The three largest values for each parameter appear in boldface.

\begin{tabular}{|c|c|c|c|c|}
\hline & Cell & Calvert & $\begin{array}{c}\text { KGRK } \\
1932 \text { UTC }\end{array}$ & $\begin{array}{c}\text { KGRK } \\
2001 \text { UTC }\end{array}$ \\
\hline $\operatorname{MLCAPE}\left(\mathrm{J} \mathrm{kg}^{-1}\right)$ & & 6544 & 6544 & 6544 \\
\hline$\Delta V_{0-6}\left(\mathrm{~m} \mathrm{~s}^{-1}\right)$ & & 8.5 & 18.5 & 18.6 \\
\hline \multirow{10}{*}{$\mathrm{SRH}_{0-1}\left(\mathrm{~m}^{2} \mathrm{~s}^{-2}\right)$} & 1851D & 14.7 & 17.3 & 7.0 \\
\hline & 1908A & -2.1 & 6.9 & 4.9 \\
\hline & 1924A & 2.7 & 7.0 & 3.6 \\
\hline & 1936A.1 & -36.9 & -16.5 & -0.7 \\
\hline & 1936A.2 & -7.2 & 7.1 & 6.3 \\
\hline & $1956 \mathrm{~A}$ & -1.9 & 8.9 & 6.1 \\
\hline & $2002 \mathrm{~A}$ & -7.6 & 4.5 & 4.8 \\
\hline & 2007A & -33.5 & -11.0 & 1.9 \\
\hline & $2013 \mathrm{~A}$ & -16.6 & -2.0 & 3.1 \\
\hline & 2019A & -33.3 & -10.8 & 2.0 \\
\hline \multirow{10}{*}{$\mathrm{SRH}_{0-3}\left(\mathrm{~m}^{2} \mathrm{~s}^{-2}\right)$} & 1851D & 36.8 & 47.8 & -49.0 \\
\hline & $1908 \mathrm{~A}$ & 5.6 & 37.8 & -66.9 \\
\hline & $1924 \mathrm{~A}$ & 2.5 & 19.7 & -81.4 \\
\hline & 1936A.1 & -67.0 & 2.8 & -117.4 \\
\hline & 1936A.2 & 10.0 & 59.0 & -49.8 \\
\hline & $1956 \mathrm{~A}$ & 13.8 & 51.7 & -53.9 \\
\hline & $2002 \mathrm{~A}$ & -0.5 & 41.5 & -66.3 \\
\hline & $2007 \mathrm{~A}$ & -46.3 & 29.9 & -90.4 \\
\hline & $2013 \mathrm{~A}$ & -21.0 & 29.6 & -82.1 \\
\hline & 2019A & -45.6 & 30.7 & -89.6 \\
\hline LCL (m) & & 1000 & 1000 & 1000 \\
\hline
\end{tabular}

percell distributions, but also nearly every value lies below the 10th percentile. The $0-6-\mathrm{km}$ shear values for this event (Fig. 12) also fall below the 25th percentile for all distributions, however, the values for both of the KGRK wind profiles (see Table 1) fall well outside of the portion of the distribution occupied by the nonsupercell regime.

Noting that the values of MLCAPE are generally larger for supercells than for nonsupercells (Fig. 9), it would seem that composite parameters that include the CAPE along with shear might characterize this environment as being supportive of supercells. The EHI is one such composite parameter and is illustrated in Fig. 13. While certain combinations of cell motions and wind profiles indeed yield EHI values above the 25th percentile for "nontornadic supercells," the vast majority of combinations do not. In fact, the median value of all wind profile-cell motion combinations is nearly 
TABLE 2. Same as in Table 1 but for composite parameters.

\begin{tabular}{|c|c|c|c|c|}
\hline & Cell & Calvert & $\begin{array}{c}\text { KGRK } \\
1932 \text { UTC }\end{array}$ & $\begin{array}{c}\text { KGRK } \\
2001 \text { UTC }\end{array}$ \\
\hline \multirow[t]{10}{*}{$\mathrm{EHI}_{0-1}$} & $1851 \mathrm{D}$ & 0.60 & 0.71 & 0.29 \\
\hline & 1908A & -0.09 & 0.28 & 0.20 \\
\hline & 1924A & 0.11 & 0.28 & 0.15 \\
\hline & 1936A.1 & -1.51 & -0.68 & -0.03 \\
\hline & 1936A.2 & -0.29 & 0.29 & 0.26 \\
\hline & 1956A & -0.08 & 0.36 & 0.25 \\
\hline & $2002 \mathrm{~A}$ & -0.31 & 0.18 & 0.20 \\
\hline & 2007A & -1.37 & -0.45 & 0.08 \\
\hline & $2013 \mathrm{~A}$ & -0.68 & -0.08 & 0.13 \\
\hline & 2019A & -1.36 & -0.44 & 0.08 \\
\hline \multirow[t]{10}{*}{ SCP } & 1851D & 0.57 & 2.37 & -2.75 \\
\hline & 1908A & 0.09 & 1.88 & -3.75 \\
\hline & $1924 \mathrm{~A}$ & 0.04 & 0.98 & -4.56 \\
\hline & 1936A.1 & -1.04 & 0.14 & -6.58 \\
\hline & 1936A.2 & 0.16 & 2.93 & -2.79 \\
\hline & 1956A & 0.21 & 2.57 & -3.02 \\
\hline & $2002 \mathrm{~A}$ & -0.01 & 2.06 & -3.72 \\
\hline & 2007A & -0.72 & 1.48 & -5.07 \\
\hline & $2013 \mathrm{~A}$ & -0.33 & 1.47 & -4.60 \\
\hline & 2019A & -0.71 & 1.52 & -5.02 \\
\hline \multirow[t]{10}{*}{ STP } & 1851D & 0.27 & 0.70 & 0.28 \\
\hline & 1908A & -0.04 & 0.28 & 0.20 \\
\hline & $1924 \mathrm{~A}$ & 0.05 & 0.28 & 0.15 \\
\hline & 1936A.1 & -0.69 & -0.67 & -0.03 \\
\hline & 1936A.2 & -0.13 & 0.29 & 0.26 \\
\hline & 1956A & -0.04 & 0.36 & 0.25 \\
\hline & $2002 \mathrm{~A}$ & -0.14 & 0.18 & 0.19 \\
\hline & $2007 \mathrm{~A}$ & -0.62 & -0.44 & 0.08 \\
\hline & $2013 \mathrm{~A}$ & -0.31 & -0.08 & 0.12 \\
\hline & 2019A & -0.62 & -0.43 & 0.08 \\
\hline
\end{tabular}

equivalent to the median value for T03's distribution of nonsupercells, although many of the combinations appear to cluster in the portion of the T03 distribution between the median value for nonsupercells and the 25th percentile for nontornadic supercells.

The SCP provides the strongest evidence that the environment associated with this event may have been capable of supporting supercells. However, only 8 of the 30 total wind profile-cell motion combinations exceed the 25th percentile value for nontornadic supercells $(\mathrm{SCP}=1.3)$ and none of these combinations exceed the median value of any of the three T03 supercell distributions (Fig. 14). Furthermore, the median value of all wind profile-cell motion combinations is approximately equivalent to the median value for nonsupercells.

It is clear from the comparison of the T03 distributions and the corresponding values for this environment that the motion of some cells, most notably the severely deviate motion of cells 1851D, 1956A, and the second segment of 1936A (Tables 1 and 2), yielded conditions that were similar to conditions associated with super-

\section{Mixed-Layer CAPE}

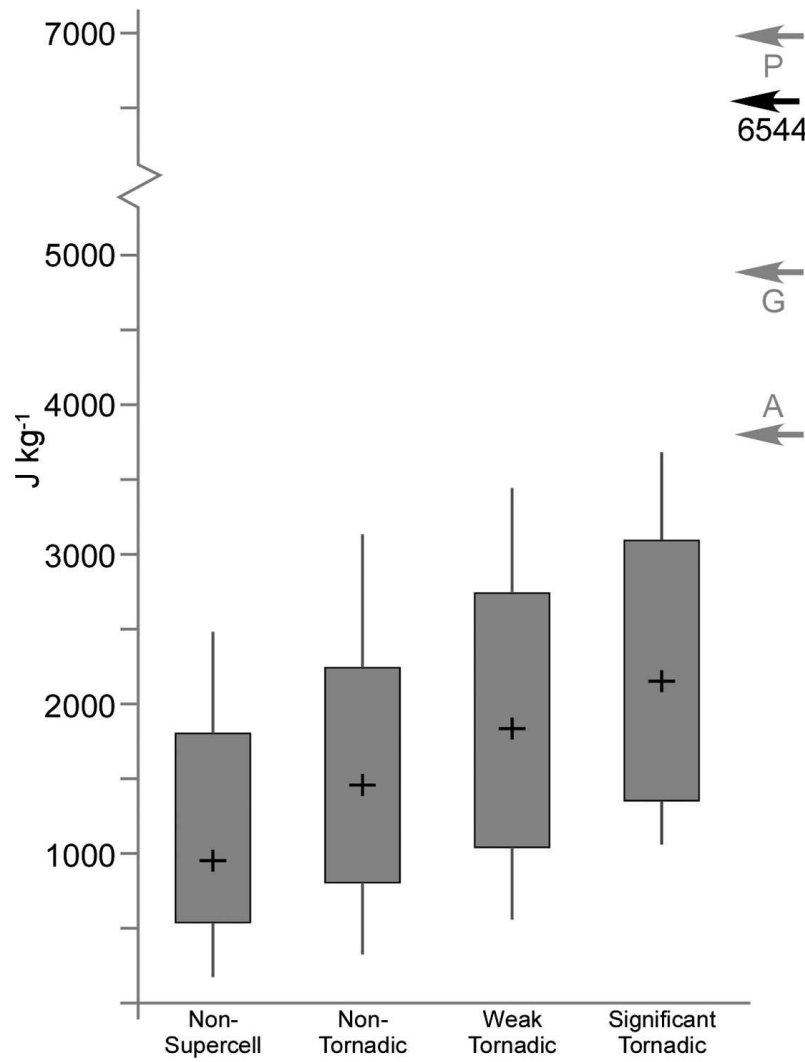

FIG. 9. Box and whiskers plot of mixed-layer CAPE values ( $\mathrm{J} \mathrm{kg}^{-1}$ ) from Thompson et al. (2003) for (from left to right) nonsupercells, nontornadic supercells, supercells producing weak tornadoes $(\mathrm{F} 0-\mathrm{F} 1)$, and supercells producing significant $(\geq \mathrm{F} 2)$ tornadoes. The shaded box covers the 25 th-75th percentiles, the whiskers extend to the 10th and 90th percentiles, and the median values are indicated with plus signs. The corresponding value for this event is indicated with a black arrow. Values associated with the Plainfield, IL (P), Grand Island (G), and Ames, IA (A) events are shown with gray arrows on the right.

cells. However, most of the wind profile-cell motion combinations crafted from the observations of this case more closely resembled environments associated with nonsupercells. Based on this result it appears that this environment was, at best, only marginally favorable for supercells.

\section{c. Expected tornado potential}

T03 determined that the LCL, $\mathrm{SRH}_{0-1}$, and significant tornado parameter $\left\{\mathrm{STP}=\left[\mathrm{MLCAPE} \cdot \Delta V_{0-6}\right.\right.$. $\left.\left.\mathrm{SRH}_{0-1} \cdot(2000-\mathrm{LCL})\right] / 3 \times 10^{9} ; \mathrm{T} 03\right\}$ were found to most effectively discriminate between nontornadic supercell environments and significantly tornadic (tornadoes producing $\mathrm{F} 2$ or greater damage) supercell environments. The values of $\mathrm{SRH}_{0-1}$ and LCL for this 


\section{0-1 km Storm-Relative Helicity}

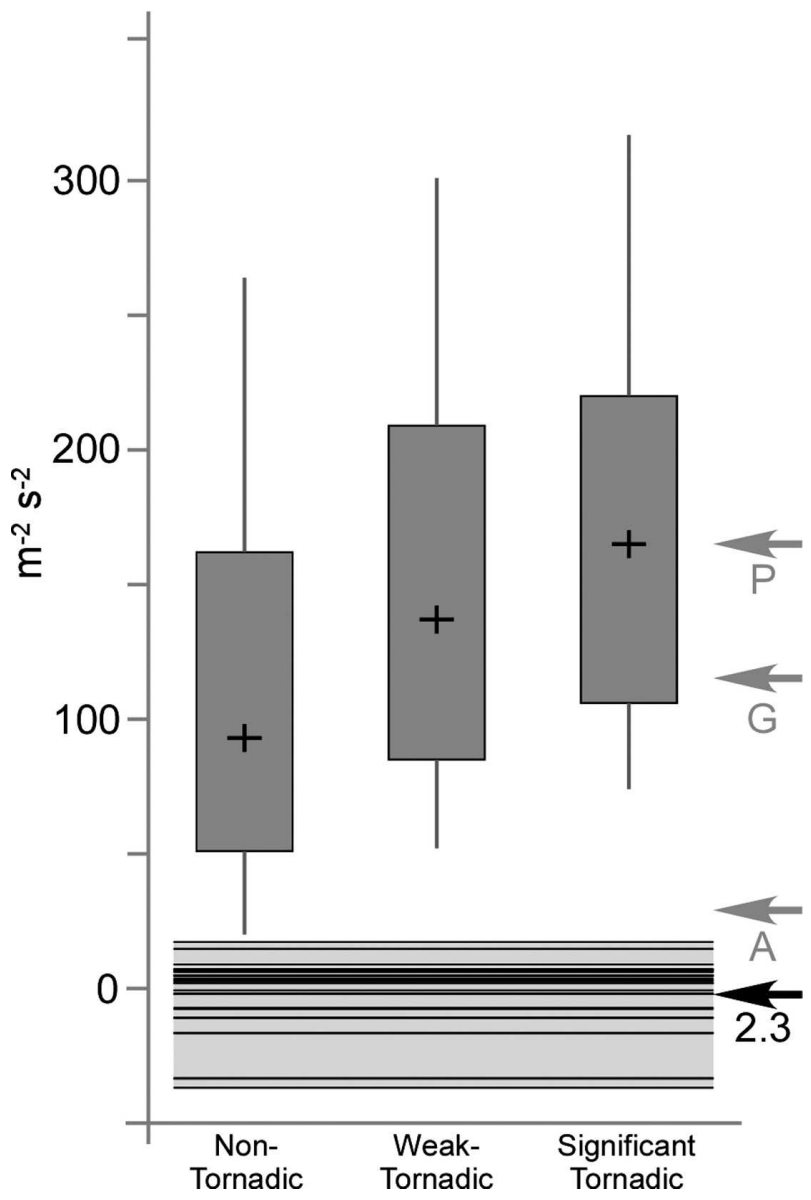

FIG. 10. Same as in Fig. 9 but for the $0-1-\mathrm{km} \mathrm{SRH}\left(\mathrm{m}^{2} \mathrm{~s}^{-2}\right)$. All combinations of wind profiles and cells listed in Table 1 are illustrated with black lines. The envelope of all combinations appears as a light gray box. The median value for all combinations is shown with the black arrow on the right.

environment are listed in Table 1 while the values of SCP are listed in Table 2.

Based on the LCL alone (Fig. 15) (and given that supercells were present), this environment would appear to be supportive of significant tornadoes. However, this is not the case when considering the $\mathrm{SRH}_{0-1}$ (Fig. 10). Not a single wind profile-cell motion combination resides within the 10th-90th percentiles of either the weak-tornadic or significant-tornadic distributions. Even the STP values for this event, which should capture the dependence of tornado strength on MLCAPE (Fig. 9), do not indicate significant tornado potential (Fig. 16). In fact, only one wind profile-cell motion combination falls above the 25th percentile of the weak-tornadic distribution and no combination has a value greater than the 25 th percentile of the significanttornadic distribution. Therefore, based on these 1D

\section{0-3 km Storm-Relative Helicity}

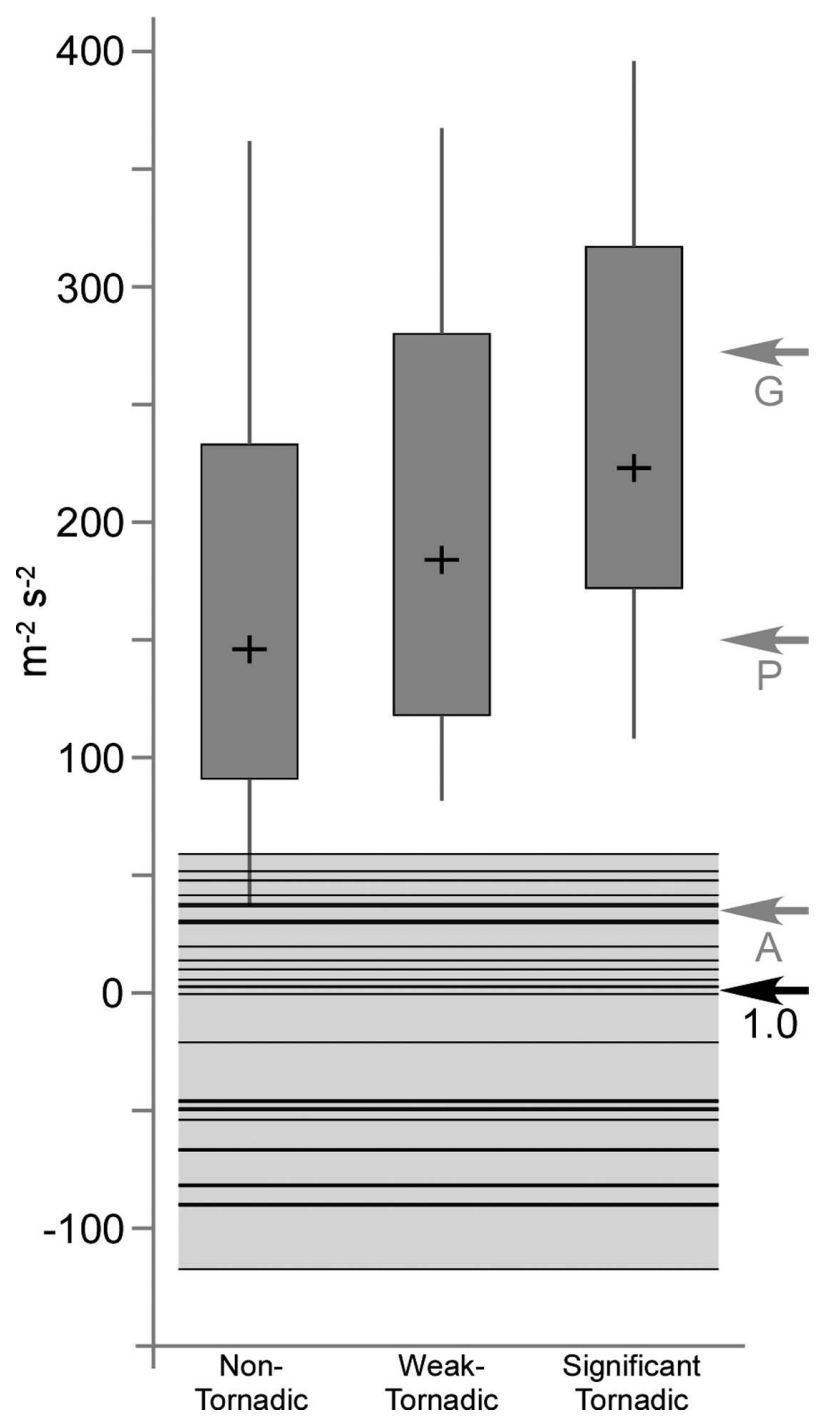

FIG. 11. Same as in Fig. 10 but for the $0-3-\mathrm{km} \mathrm{SRH}\left(\mathrm{m}^{2} \mathrm{~s}^{-2}\right)$.

metrics alone, this environment did not appear to be favorable for significant tornadoes.

\section{d. Preexisting boundaries}

While characterizing the expected thunderstorm type for a given environment based solely on onedimensional profiles of state variables has shown some capacity for distinguishing supercell from nonsupercell environments, the complete characterization of a prestorm environment must also include the 3D structure of the atmosphere. We will show in forthcoming sections that the preexisting boundaries were instrumental in the evolution of this event. Thus, this section is devoted to identifying the position and type of boundaries present in this event. 


\section{0-6 km Vector Shear Magnitude}

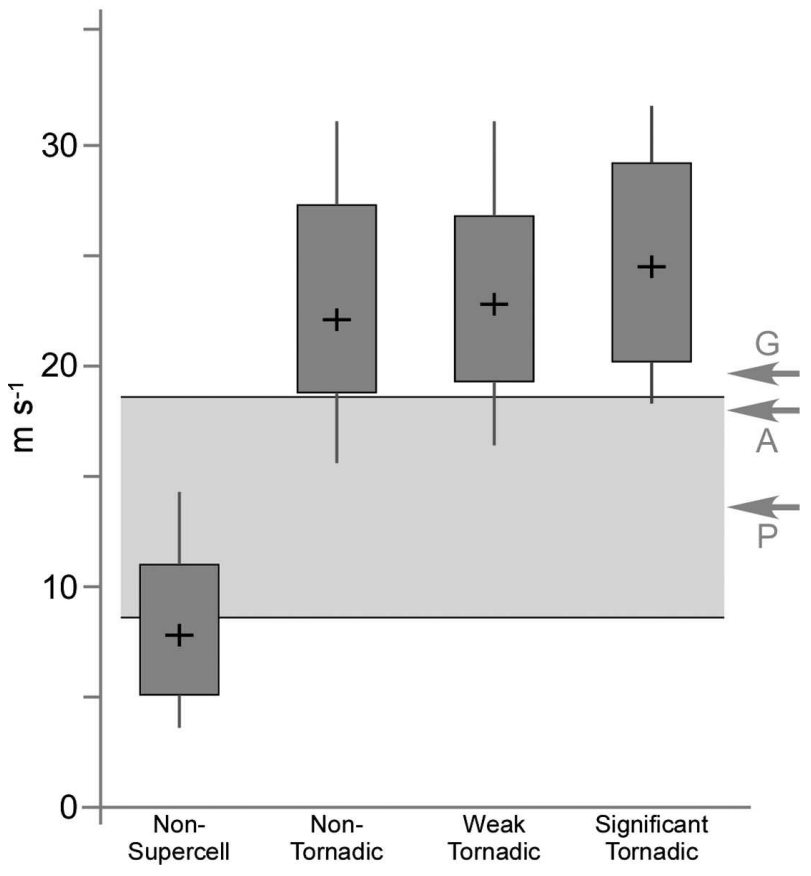

FIG. 12. Same as in Fig. 10 but for the $0-6-\mathrm{km}$ vector shear magnitude $\left(\mathrm{m} \mathrm{s}^{-1}\right)$ and including the "nonsupercell" category.

Boundary positions during this event were identified based on the locations of varying combinations of temporally coherent features evident in the available radar, satellite, and Automated Surface Observing System (ASOS) data:

- Low-level radial velocity convergence sampled in the $0.5^{\circ}$ elevation scans of the KGRK radar,

- Reflectivity finelines (Wilson and Schreiber 1986) from the KGRK radar $^{5}$,

- Cloud lines or cloud field discontinuities in the hourly 1-km visible images from the GOES-9 satellite,

- Times and locations of airmass changes based on hourly ASOS observations.

The easternmost airmass boundary in place across central Texas on 27 May (illustrated as the scalloped curve in Fig. 17) can be characterized most accurately as a dryline (Corfidi 1998): dry-bulb temperatures were generally higher and dewpoint temperatures were lower immediately to the west of the southwestnortheast boundary (Table 3 ). Winds on the west side

\footnotetext{
${ }^{5}$ Boundaries identified using low-level radial velocity convergence and/or reflectivity fine lines were within $\sim 70 \mathrm{~km}$ of the KGRK radar and were therefore observable at elevations less than $\sim 900 \mathrm{~m}$.
}

\section{0-1 km Energy-Helicity Index}

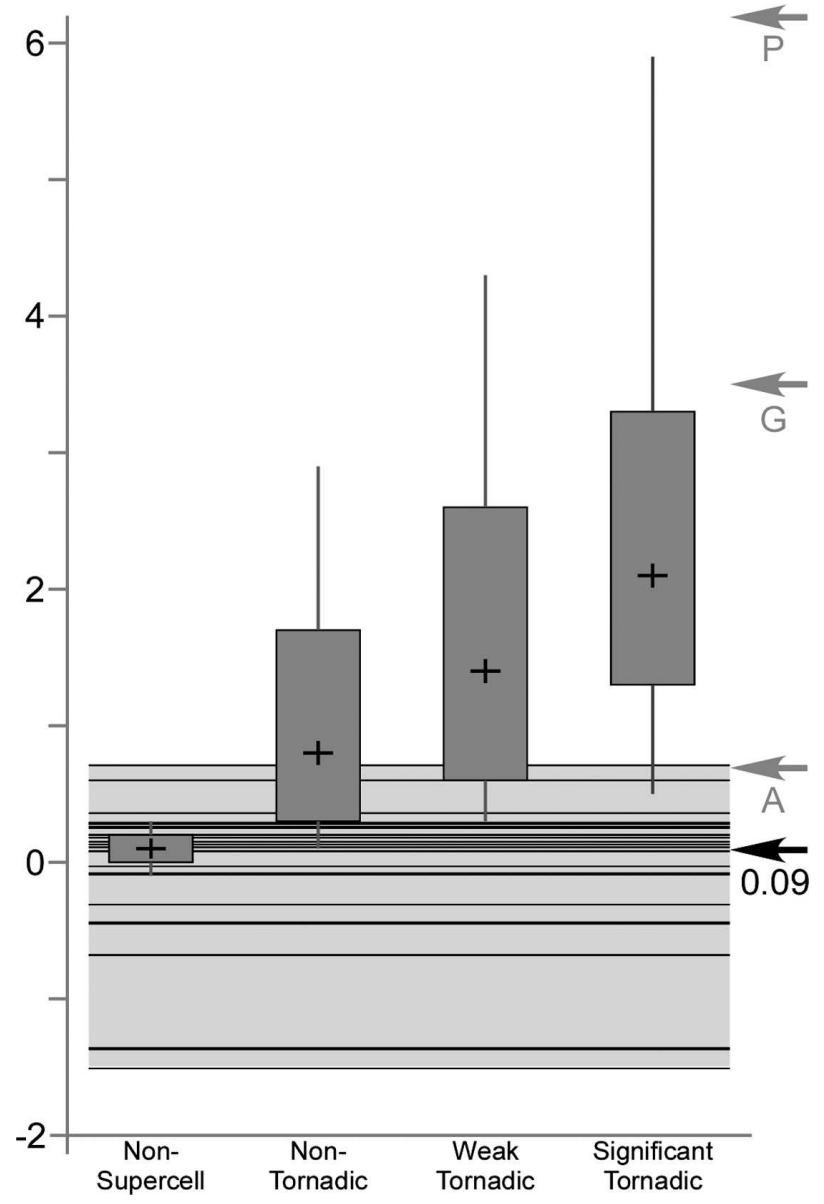

FIG. 13. Same as in Fig. 12 but for the 0-1-km EHI.

of the dryline were generally from the west although in west-central Texas, winds behind the dryline appeared to be from the north-northeast (viz. Junction winds in Table 3). The dryline was primarily manifested as a cloud field discontinuity (Fig. 17) but also appeared as reflectivity fine line (Fig. 18). It was observed to travel eastward at a speed of approximately $3 \mathrm{~m} \mathrm{~s}^{-1}$ across central Texas during daylight hours on 27 May, although a slower more southerly motion was observed over west-central Texas.

The cold front in place across central Texas on 27 May (Fig. 17) delineated "cool," moist air to the north and either "hot," dry air to the south (for the portion of the cold front west of the dryline) or "warm," moist air to the east (for the portion of the cold front that had overtaken the dryline). The small temperature deficit in the air mass north of the cold front appeared to be partly masked by the diurnal temperature cycle. Note that the temperatures at Gray Air Force Base (GRK) and Killeen (ILE) actually increased following the cold 


\section{Supercell Composite Parameter}

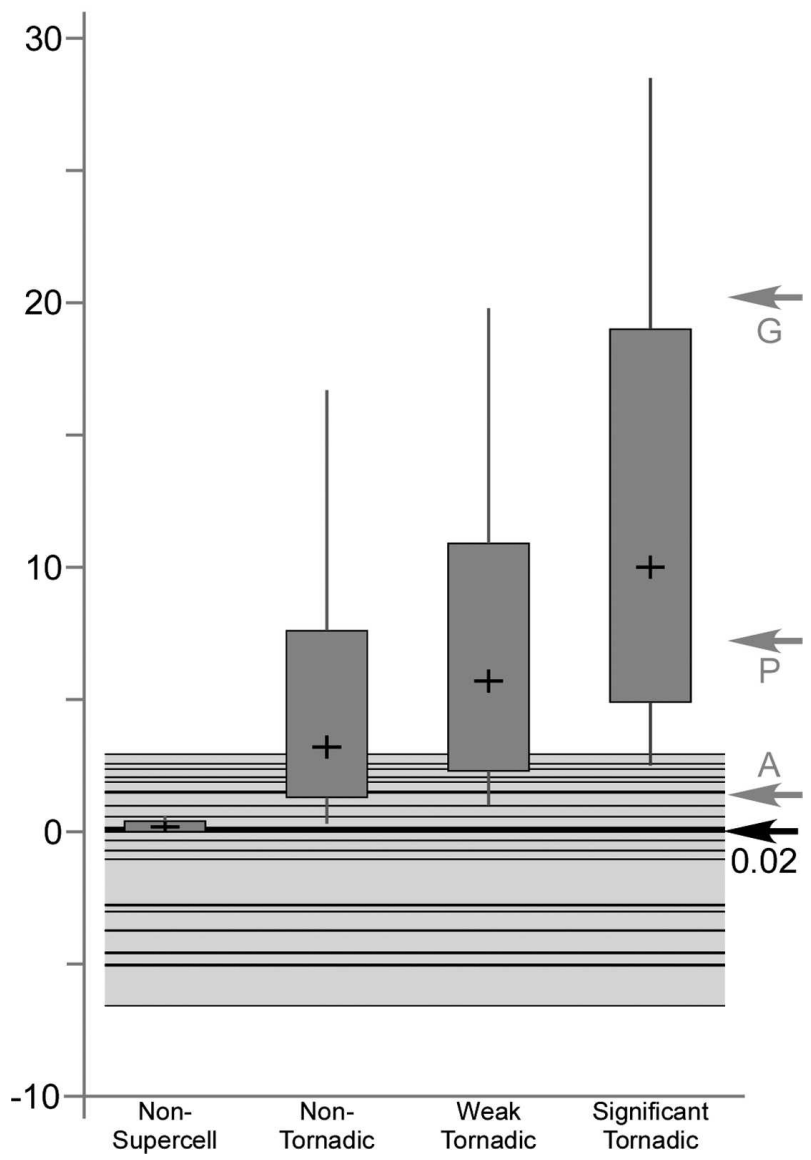

FIG. 14. Same as in Fig. 12 but for the SCP.

frontal passage (Table 4). In this regard, the cold front may be more accurately characterized as a trough or baroclinic trough (Sanders 2005) in places. However, for the sake of consistency with the boundary's identity prior to the mitigation of the temperature gradient by daytime heating, the term cold front will be used. Observed winds behind the front were generally from the north. As illustrated in Fig. 17, the cold front had no presentation in the cloud field west of the dryline throughout the analysis period. However, it did appear as a reflectivity fine line (Fig. 18). The front was observed to move southward at approximately $6 \mathrm{~m} \mathrm{~s}^{-1}$.

Visible channel data from both the GOES-8 and GOES-9 satellites clearly revealed an expansive southwestward-moving gravity wave extending eastward from central Texas into Louisiana and Mississippi (Corfidi 1998). This gravity wave emanated from a nocturnal mesoscale convective system (MCS) over Arkansas and had reached a Waco-College Station-Houston, Texas, line by 1700 UTC (see Fig. 17). The gravity wave manifested as a transient, localized enhancement in the

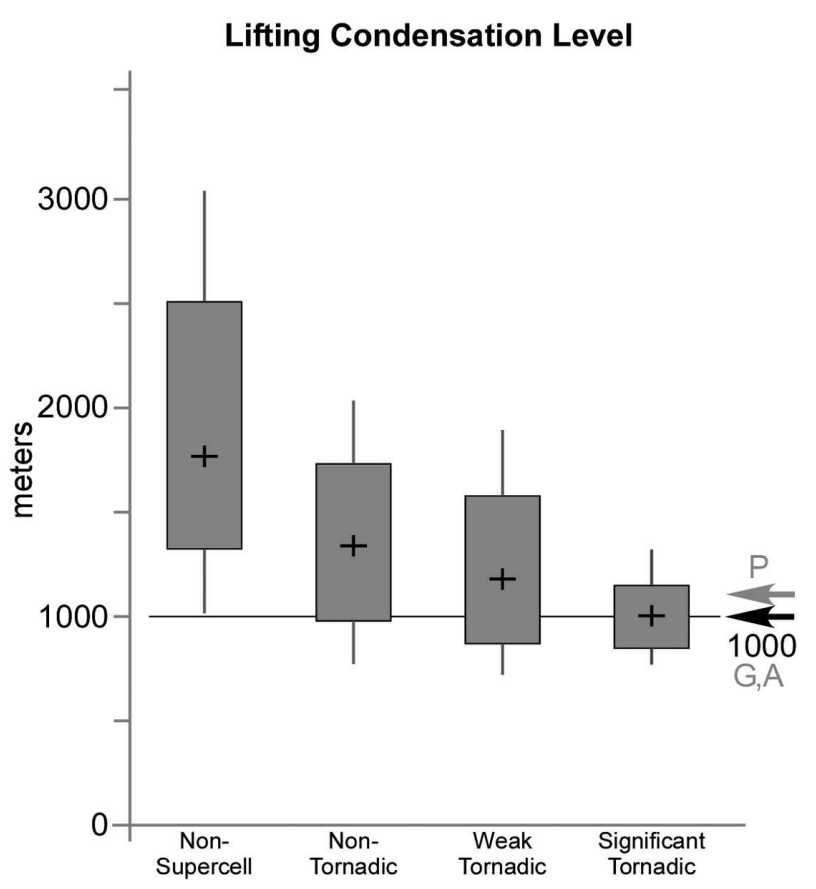

FIG. 15. Same as in Fig. 12 but for the LCL.

cloud cover (e.g., the localized northwest-southeastoriented cloud field just northwest of Calvert at 1700 UTC, as illustrated in Fig. 17). It has been proposed that the gravity wave may have played a role in the initiation of the first deep convection near Waco around 1730 UTC (NOAA 1998, their appendix B). Corfidi (1998) went further by speculating that the gravity wave was "critical for realizing and maintaining supercellular convection." These issues will be addressed in greater detail in section $3 \mathrm{~b}$.

\section{Storm propagation and maintenance}

Storm motion can be decomposed into translation and propagation components. The translation component is governed by the winds in the cloud-bearing layer of the atmosphere and the propagation component is governed by cell redevelopment. The propagation component can be further decomposed into a contribution from discrete and (quasi)continuous redevelopment. The distinction between the two subcategories is primarily one of spatial separation between new updrafts: in quasi-continuous redevelopment, new cells are nearly indistinguishable from existing cells. The distinction between the two categories is based on more than just geometry though. Quasi-continuous redevelopment, owing to the small spatial separation between new and old cells, produces smaller entrainment rates of low- $\theta_{e}$ midtropospheric air into the new updrafts and 


\section{Significant Tornado Parameter}

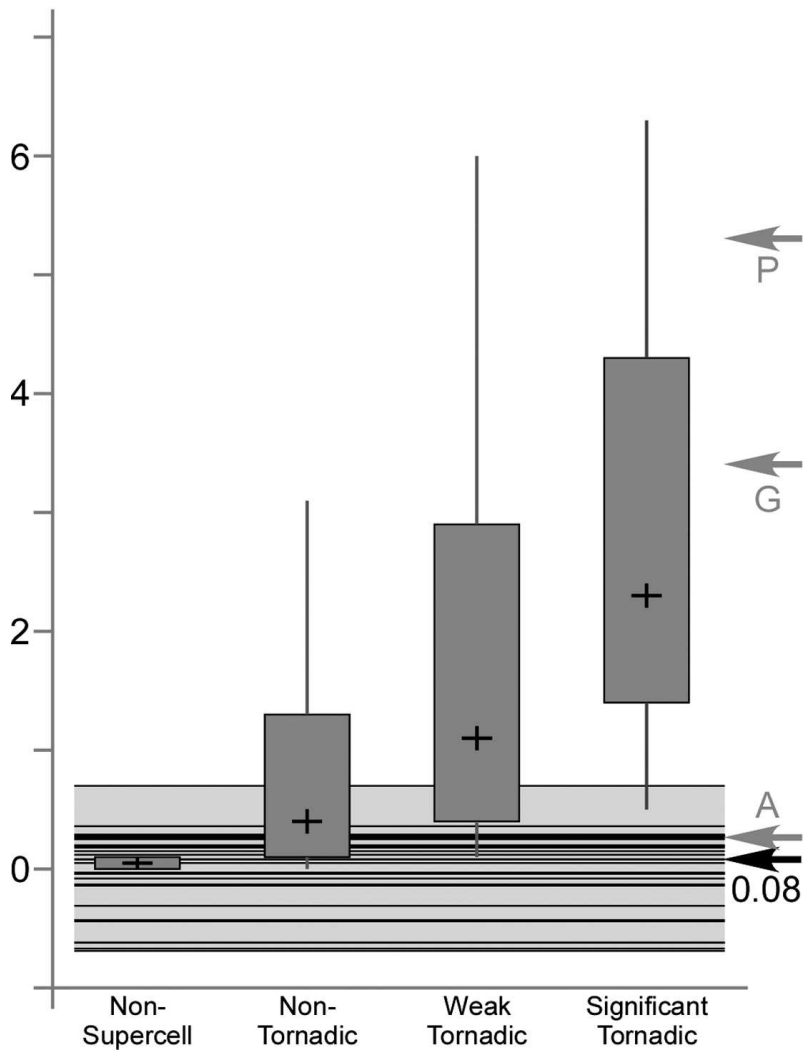

FIG. 16. Same as in Fig. 12 but for the significant tornado parameter.

therefore tends to yield longer-lived updrafts (Fovell and Ogura 1989).

Given the back-building character of storm motion in this case, it appears that cell redevelopment dictated storm motion. The analysis of this event conducted by Magsig et al. (1998a,b) revealed three separate "storms" during the tornadic phase of this event: the Lake Belton, Jarrell, and Pedernales Valley storms. Each storm developed along one of the preexisting boundaries southwest of the previous (ongoing) storm, thus some measure of discrete cell redevelopment took place during this event. However, it is uncertain whether storm propagation was driven by the quasicontinuous redevelopment of a few (perhaps as few as three) cells or the discrete redevelopment of numerous cells that, owing to differential cell separations, could be partitioned into three sequences and thus three storms. Given the presence of supercells it is also necessary to determine what, if any, contribution was made to the back-building propagation from supercell dynamics (e.g., Rotunno and Klemp 1982; Davies-Jones 1984; Rotunno and Klemp 1985). The possible role played by the gravity wave identified by Corfidi (1998) must also be identified. These issues are addressed in this section.

\section{a. Methodology}

To address the mechanisms responsible for cell redevelopment, a detailed analysis of the radar data available for this case was undertaken. The full radar dataset consisted of WSR-88D level-II data from the New Braunfels, Texas, radar (KEWX) and Fort Worth, Texas, radar (KFWS) as well as level-III data from the central Texas radar (KGRK). Level-II data is the radar's most comprehensive data format that includes 256 data levels and all elevation angles and has a range bin spacing of $1 \mathrm{~km}(0.25 \mathrm{~km})$ for reflectivity (velocity). Level-III data is a more selective data format that includes 16 data levels and only the four lowest elevation angles. Data are also on a Cartesian grid with $1-\mathrm{km}$ grid spacing.

Although further away from the storms than KGRK, we chose to use the level-II data from KEWX and KFWS for updraft identification because the data were more comprehensive and could be visualized more flexibly using the WSR-88D Algorithm Testing and Display System (NSSL 2000). Updraft identification and positioning were accomplished by using multiple elevation angles and vertical cross sections to establish vertical continuity and multiple times to establish temporal continuity and to develop cell tracks. Special attention was paid to the location of storm summits and weakecho regions or bounded weak-echo regions as these are particularly good indicators of updraft position. Cell position also reflected cell age: cell position was coincident with elevated reflectivity maxima for new cells, since the updraft typically dominates the cell in the early stages, and low-level reflectivity maxima for decaying cells, since the precipitation laden downdraft typically dominates the cell in late stages. The tracking of a given cell began at the first appearance of elevated radar echo and terminated when either the cell was absorbed into a longer-lived cell or, after a period of echo height reduction (cell decay), the cell could no longer be distinguished from the surrounding radar echo. The accuracy of the diagnosed temporal coherence and motion of cells was primarily limited by the radar-sampling interval, which was $6 \mathrm{~min}$. The effective sampling interval was generally less than 6 min since the two radars did not sample the same area at the same time.

\section{b. Cell redevelopment}

The cell identification performed for this case revealed that discrete cell redevelopment controlled the 


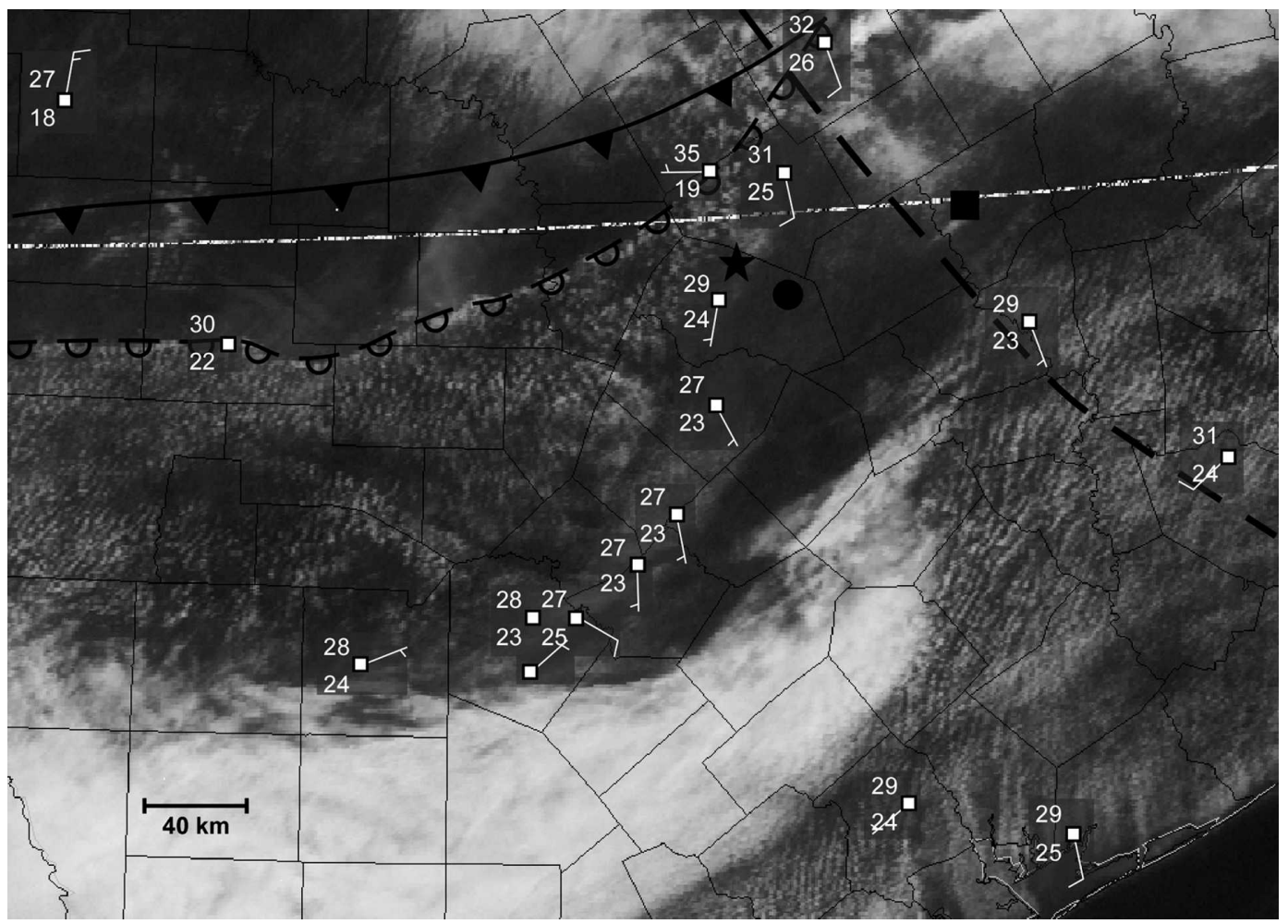

FIG. 17. Boundaries, surface conditions, and cloud field at 1700 UTC. The cold front appears as the curve with filled triangles, the dryline is the scalloped curve, and the gravity wave position is indicated with a thick dashed curve. The temperature and dewpoint $\left({ }^{\circ} \mathrm{C}\right.$ ) along with winds (half barbs represent $2.5 \mathrm{~m} \mathrm{~s}^{-1}$ and full barbs represent $5 \mathrm{~m} \mathrm{~s}^{-1}$ ) are included for selected stations. The cloud field image comes from the GOES-9 visible channel. The location of Jarrell, the KGRK radar, and Calvert are indicated with a star, circle, and square, respectively.

propagation of the "Jarrell" and "Pedernales Valley" storms. As illustrated in Table 5, both storms were composed of numerous discrete cells. Sequential cell redevelopment was generally found to occur farther southwest throughout the event with individual cells generally traveling from west to east (Fig. 8). Thus, the southwest motion of the storm was dictated by discrete cell redevelopment.

In an attempt to identify the role of the preexisting boundaries in discrete cell redevelopment, statistics on the location of cell initiation were composited (Table
5). The location of cell initiation was clearly not restricted to a single boundary but instead seemed to occur just as often on the cold front, storm-generated gust front, and dryline. In fact, of the 16 cells whose origin could be identified, the distribution was as follows:

- Six cells developed on the cold front,

- Five cells developed on the storm-generated gust front, and

- Five cells developed on the dryline.

An illustration of all boundaries at 2002 UTC ap-

TABLE 3. Observed dry-bulb temperature $(T)$ and dewpoint temperature $\left(T_{d}\right)$ changes across the dryline, wind velocity on the west side of the dryline, and the time window of dryline passage. The changes are computed based on the nearest hourly observations for five central Texas surface observation stations before and after dryline passage; a positive value indicates that the value to the east of the dryline was lower than the value to the west.

\begin{tabular}{|c|c|c|c|c|}
\hline Station (ID and lat-lon) & $\Delta T\left({ }^{\circ} \mathrm{C}\right)$ & $\Delta T_{d}\left({ }^{\circ} \mathrm{C}\right)$ & Wind & $\begin{array}{c}\text { Dryline passage } \\
\text { (UTC) }\end{array}$ \\
\hline Gray Air Force Base (GRK: $\left.31.7^{\circ} \mathrm{N}, 97.8^{\circ} \mathrm{W}\right)$ & 0 & -2 & $5 \mathrm{~m} \mathrm{~s}^{-1}$ from $270^{\circ}$ & $1600-1700$ \\
\hline Killeen Municipal Airport (ILE: $31.7^{\circ} \mathrm{N}, 97.6^{\circ} \mathrm{W}$ ) & +1 & -1 & $3 \mathrm{~m} \mathrm{~s}^{-1}$ from $240^{\circ}$ & $1533-1633$ \\
\hline Fort Hood (HLR: $\left.31.1^{\circ} \mathrm{N}, 97.7^{\circ} \mathrm{W}\right)$ & +2 & -4 & $4 \mathrm{~m} \mathrm{~s}^{-1}$ from $270^{\circ}$ & $1600-1700$ \\
\hline Burnet (BMQ: $\left.30.7^{\circ} \mathrm{N}, 98.2^{\circ} \mathrm{W}\right)$ & +2 & -2 & $3 \mathrm{~m} \mathrm{~s}^{-1}$ from $300^{\circ}$ & $1553-1653$ \\
\hline Junction (JCT: $\left.30.5^{\circ} \mathrm{N}, 99.8^{\circ} \mathrm{W}\right)$ & +2 & -2 & $4 \mathrm{~m} \mathrm{~s}^{-1}$ from $10^{\circ}$ & $1853-1953$ \\
\hline
\end{tabular}




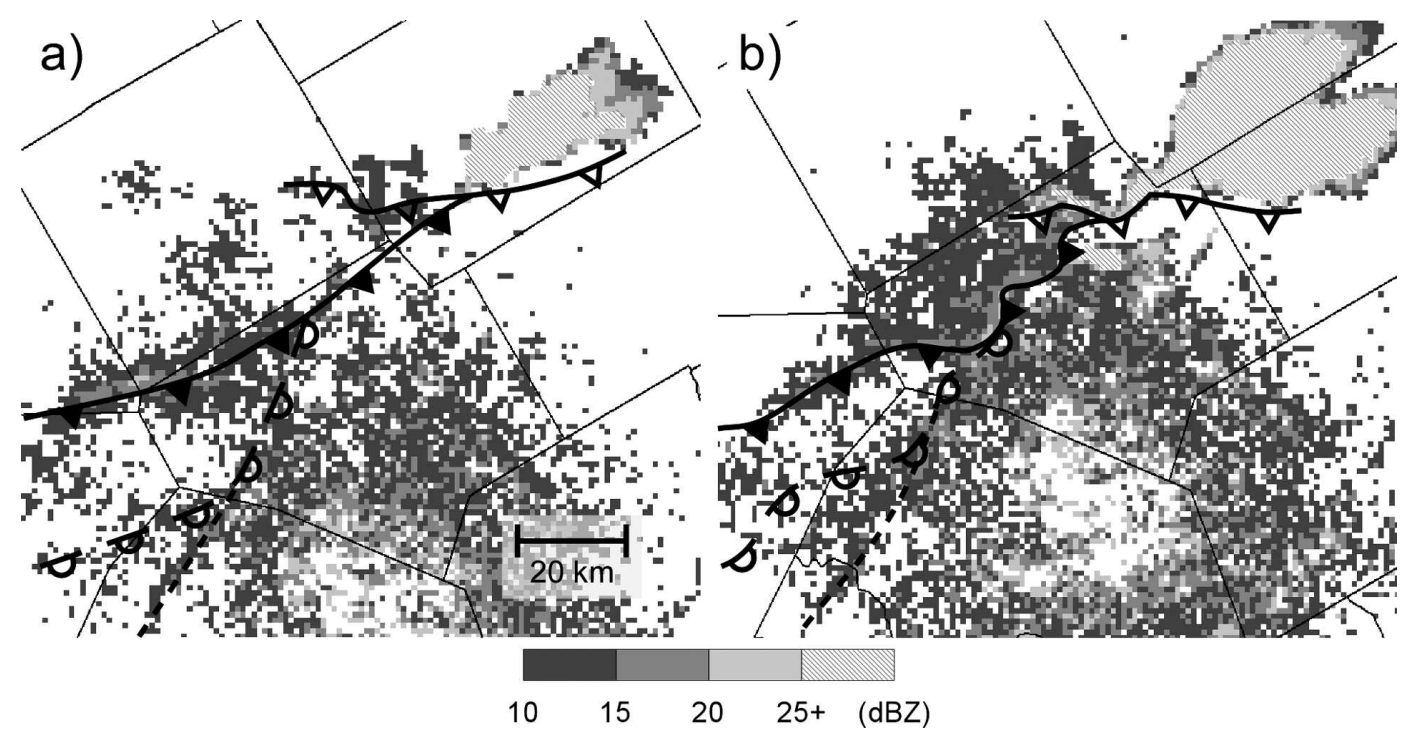

FIG. 18. Radar manifestation of the boundaries at (a) 1804 and (b) 1902 UTC. Reflectivity fields from the $0.5^{\circ}$ sweep of the central TX radar appear in both (a) and (b). The notations for boundaries are the same as in Fig. 17. In addition, the storm-generated gust front appears as the curve with open triangles and the nonclassical mesoscale circulation appears as a thin dashed curve.

pears in Fig. 19. The storm-generated gust front appeared in the radar data as a reflectivity fineline and/or radial convergence signature (Figs. 18 and 19).

Cell initiation along the cold front occurred exclusively on its extent south of the storm gust front where the cold front first overtook the dryline and thus where it first penetrated into the air mass with the highest surface equivalent potential temperature. This portion of the cold front will hereafter be referred to as the frontal segment. The frontal segment appeared to be more favorable than locations along the cold front west of the dryline because the lower surface equivalent potential temperature to the west of the dryline likely yielded a larger convective inhibition.

All of the cells that developed on the stormgenerated gust front developed south through west of the gust front cusp, the prominent inflection in the gust front (see Fig. 19 for the location of the cusp on the gust front). The portion of the gust front south through west of the cusp will be referred to as the distorted gust front. The configuration of the distorted gust front bears a striking resemblance to the configuration of the rearflank gust front associated with an archetypical supercell (e.g., Lemon and Doswell 1979). While the contribution to this configuration from the storm-scale rotation of the storm complex, as in the archetypical supercell (Klemp et al. 1981; Brooks et al. 1994), cannot be wholly discounted, the gust front distortion of this case did not require storm-scale rotation. It is posited herein that the preexisting horizontal shear across the cold front (i.e., the horizontal shear of the boundaryparallel winds) made a significant, if not dominant, con-

TABLE 4. Same as in Table 3, but for changes across the cold front, wind velocity on the north side of the cold front, and the time window of cold front passage. The changes are computed based on the nearest hourly observations for five central Texas surface observation stations before and after cold front passage; a positive value indicates that the value to the south of the cold front was lower than the value to the north.

\begin{tabular}{lcccc}
\hline \hline \multicolumn{1}{c}{ Station (ID and lat-lon) } & & & & $\begin{array}{c}\text { Cold front passage } \\
(\mathrm{UTC})\end{array}$ \\
\hline Gray Air Force Base (GRK: $\left.31.7^{\circ} \mathrm{N}, 97.8^{\circ} \mathrm{W}\right)$ & +1 & +1 & $5 \mathrm{~m} \mathrm{~s}^{-1}$ from $340^{\circ}$ & $1800-1900$ \\
Killeen Municipal Airport (ILE: $\left.31.7^{\circ} \mathrm{N}, 97.6^{\circ} \mathrm{W}\right)$ & +1 & 0 & $5 \mathrm{~m} \mathrm{~s}^{-1}$ from $350^{\circ}$ & $1800-1900$ \\
Fort Hood (HLR: $\left.31.1^{\circ} \mathrm{N}, 97.7^{\circ} \mathrm{W}\right)$ & -1 & +3 & $6 \mathrm{~m} \mathrm{~s}^{-1}$ from 350 & $1800-1900$ \\
Burnet (BMQ: $\left.30.7^{\circ} \mathrm{N}, 98.2^{\circ} \mathrm{W}\right)$ & -1 & +3 & $6 \mathrm{~m} \mathrm{~s}^{-1}$ from $10^{\circ}$ & $1853-1953$ \\
Junction (JCT: $\left.30.5^{\circ} \mathrm{N}, 99.8^{\circ} \mathrm{W}\right)$ & 0 & +2 & $3 \mathrm{~m} \mathrm{~s}^{-1}$ from VRB* & $1853-1953$ \\
\hline
\end{tabular}

* Direction is variable. 
TABLE 5. Statistics for all cells identified between 1851 and 2048 UTC. The "storm" column denotes the cells associated with the Lake Belton (LB), Jarrell (J), and Pedernales Valley (PV) storms (Magsig et al. 1998a,b). The numeric part of each cell name corresponds to the time of cell initiation. Boldface text indicates the longest-lived and well-sampled cells. The tracks of the longest-lived and well-sampled cells (along with cell 1956A) appear in Fig. 8.

\begin{tabular}{|c|c|c|c|c|c|c|c|}
\hline Storm & Cell name & $\begin{array}{l}\text { Begin time } \\
\text { (UTC) }\end{array}$ & $\begin{array}{l}\text { End time } \\
\text { (UTC) }\end{array}$ & End status & $\begin{array}{l}\text { Duration } \\
(\min )\end{array}$ & Location of initiation & $\begin{array}{c}\text { Midlevel } \\
\text { mesocyclone }\end{array}$ \\
\hline $\mathrm{J}$ & $1851 \mathrm{~A}$ & $1851 ?$ & 1914 & Dissipation & $\geq 23$ & $?$ & - \\
\hline $\mathrm{J}$ & 1851B & $1851 ?$ & 1902 & Dissipation & $\geq 11$ & $?$ & - \\
\hline LB & $1851 \mathrm{C}$ & $1851 ?$ & 1908 & Merger with $1851 \mathrm{D}$ & $\geq 17$ & $?$ & - \\
\hline LB & 1851D & 1851? & 1936 & Dissipation & $\geq 45$ & ? & Yes \\
\hline $\mathbf{J}$ & 1908A & 1908 & 2002 & Dissipation & 54 & Cold front & Yes \\
\hline $\mathrm{J}$ & $1914 \mathrm{~A}$ & 1914 & 1924 & Merger with 1908A & 10 & Cold front & - \\
\hline $\mathbf{J}$ & $1924 A$ & 1924 & 1953 & Dissipation & 29 & Storm-generated gust front & Yes \\
\hline $\mathrm{J}$ & $1930 \mathrm{~A}$ & 1930 & 1941 & Merger with 1908A & 11 & Cold front & - \\
\hline $\mathbf{J}$ & 1936A & 1936 & 2031 & Dissipation & 55 & Cold front & Yes \\
\hline $\mathrm{J}$ & $1941 \mathrm{~A}$ & 1941 & 1944 & Merger with 1908A & 3 & Storm-generated gust front & - \\
\hline $\mathrm{J}$ & $1956 \mathrm{~A}$ & 1956 & 2037 & Dissipation & 41 & Storm-generated gust front & - \\
\hline $\mathrm{J}$ & $1956 \mathrm{~B}$ & 1956 & 2002 & Merger with 1956A & 6 & Cold front & - \\
\hline $\mathbf{J}$ & $2002 A$ & 2002 & 2048? & End of analysis & $\geq 46$ & Cold front & Yes \\
\hline PV & 2007A & 2007 & 2037 & Dissipation & 30 & Dryline near NCMC* & No \\
\hline PV & 2013A & 2013 & 2043 & Dissipation & 30 & Dryline near NCMC & No \\
\hline PV & 2019A & 2019 & 2048? & End of analysis & $\geq \mathbf{2 9}$ & Dryline near NCMC & No \\
\hline $\mathrm{J}$ & $2025 \mathrm{~A}$ & 2025 & 2037 & Merger with 2002A & 12 & Storm-generated gust front & - \\
\hline $\mathrm{J}$ & $2031 \mathrm{~A}$ & 2031 & $2048 ?$ & End of analysis & $\geq 17$ & Storm-generated gust front & - \\
\hline PV & 2031B & 2031 & $2048 ?$ & End of analysis & $\geq 17$ & Dryline near NCMC & - \\
\hline PV & $2037 \mathrm{~A}$ & 2037 & 2043 & Merger with 2019A & 6 & Dryline near NCMC & - \\
\hline
\end{tabular}

* NCMC: nonclassical mesoscale circulation.

tribution to the gust front distortion. Recall that the flow behind the cold front was from the north while the flow to the east of the front was from the south. It is proposed that this preexisting horizontal shear allowed the storm-generated outflow to travel more rapidly to the south on the west side of the cold front than on the east side, yielding the observed gust front distortion. As illustrated in Fig. 20, an initially undistorted east-westoriented gust front straddling a north-south-oriented wind shift boundary will become deformed by the horizontal shear, yielding a gust front distortion similar to the one observed in this event. Identifying the role played by the cold front in producing the gust front distortion is important for assessing the degree to which storm maintenance and propagation ultimately relied on the cold front. This concept will be expanded below.

The cell development that occurred on the dryline was found near the dryline's intersection with another preexisting boundary resembling a nonclassical mesoscale circulation (NCMC; Segal and Arritt 1992). An NCMC is a thermally driven secondary circulation (with a horizontal axis) resulting from a horizontal variation in surface-based sensible heat flux. Horizontal differences in surface-based heat flux typically stem from horizontally heterogeneous evapotranspiration, surface albedo, and/or subsurface thermal storage (Segal and Arritt 1992). The NCMC-like boundary of this event appeared after 1800 UTC and had presentations in the radar data as a fine line (Fig. 18) and in the visible satellite data as a cloud line (Fig. 19). No surface observations were made between this boundary and the dryline so little is known about the forcing mechanism. Its appearance late in the day suggests that it may have been the product of differences in surface albedo and/ or subsurface thermal storage.

The fact that cell development along the dryline required an interaction with another boundary while cell development along the distorted gust front and frontal segment did not is noteworthy considering that 1) all three boundaries (dryline, distorted gust front, and frontal segment) were presumably in contact with a similar airmass to the east, and 2) each of these boundaries had roughly the same orientation (approximately $30^{\circ}$ south of west to $30^{\circ}$ north of east; see Fig. 19). However, the winds behind each of these boundaries were markedly different and thus the low-level convergence and resulting forced ascent along these boundaries may have been different as well. In an attempt to quantify this difference, surface observations at 2000 UTC were used to approximate a wind vector behind each of the boundaries along with an approximate wind vector in the air mass to the east of the dryline. These winds were then projected onto a unit vector normal to each boundary (assuming identical orientations) to 

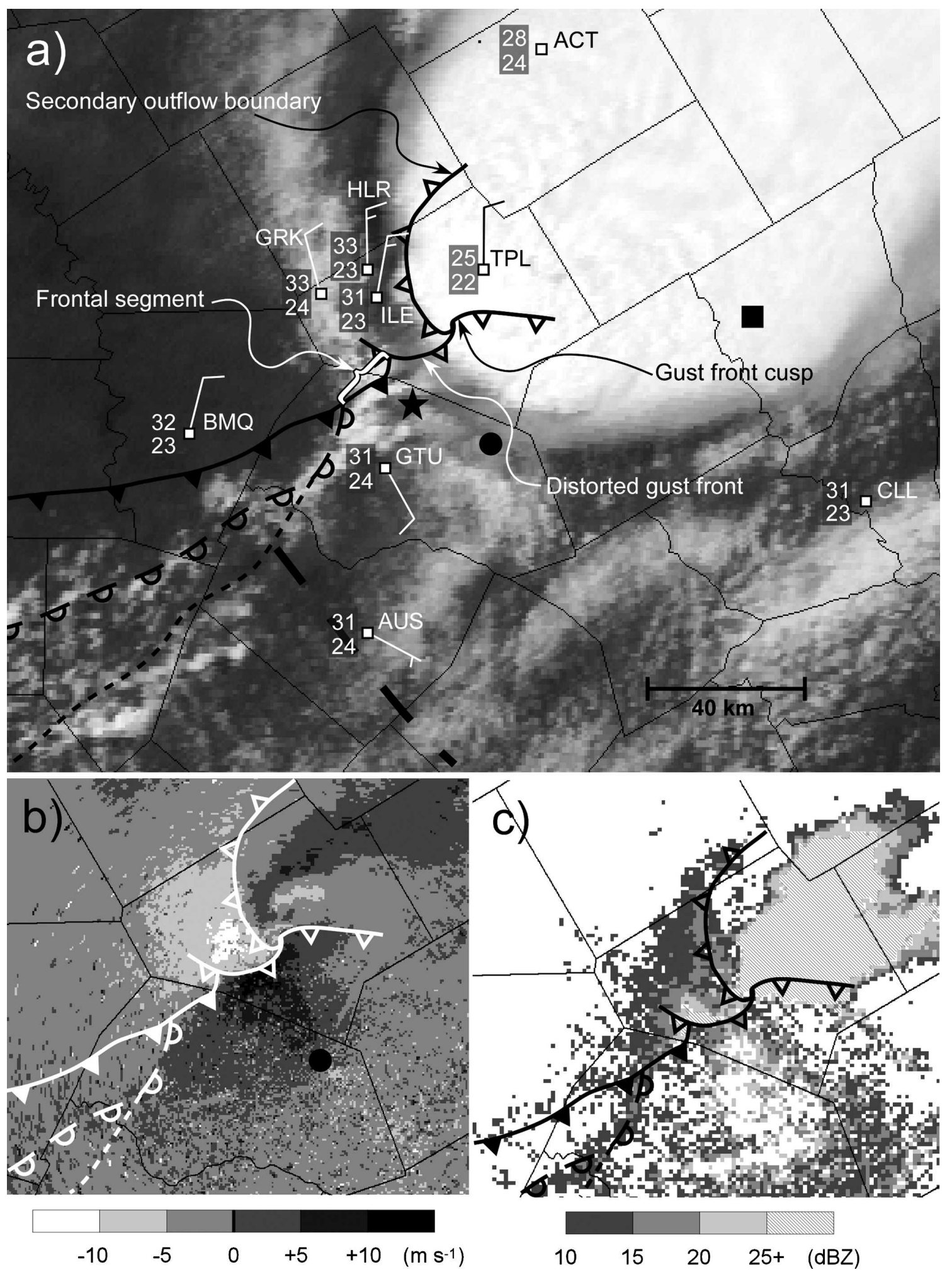

FIG. 19. Boundaries at 2000 UTC relative to (a) the cloud field from the GOES-9 visible channel and surface conditions, (b) the radial velocity field from the $0.5^{\circ}$ sweep of the central TX radar, and (c) the reflectivity field from the $0.5^{\circ}$ sweep of the central TX radar. The notations for boundaries are the same as in Figs. 17 and 18. The notations for the surface observations and locations of Jarrell, the KGRK radar, and Calvert as in Fig. 17. All panels are identically scaled. The exact position of the gravity wave was ill defined at this time; the position illustrated is a combination of a spatial extrapolation from its well-defined position farther east and a temporal extrapolation from its earlier position. 


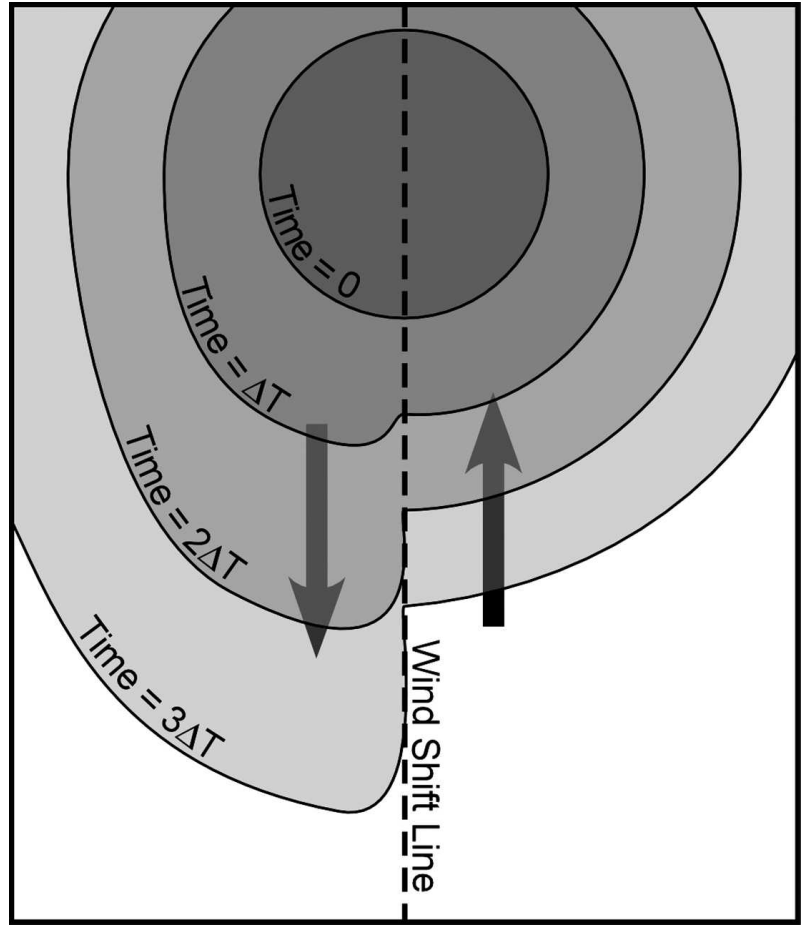

FIG. 20. Cartoon illustrating the distortion of a gust front across a wind shift line. The initial cold pool and gust front appear as the dark gray region and thin black curve at its leading edge labeled as "Time $=0$." Successive stages of the cold pool and gust front are similarly illustrated. The wind shift across which the gust front distortion forms appears as a thick dashed line with the corresponding flow illustrated with the arrows.

compute a proxy for convergence (assuming a uniform distribution of these winds along each boundary). The results are listed in Table 6. Because of uncertainties in the representativeness of the winds across the boundaries, "errors" were introduced into each wind value in an attempt to quantify the statistical significance of the differences in velocity differentials between each of the boundaries. The errors were imposed in the boundarynormal wind speeds by first specifying a maximum/ minimum $\mp N \%$ error and then populating the wind speeds within this range with an even distribution of values. Velocity differentials were then computed for all possible combinations of boundary-normal winds within the distributions and the statistical significance of the differences between the distributions of velocity differentials was computed using a Student's $t$ statistic. Results from this statistical analysis are listed in Table 7. The boundary-normal velocity differentials listed in Table 6 illustrate that the convergence along the frontal segment and distorted gust front was likely larger than the convergence along the dryline. And because the differences between the velocity differentials computed
TABLE 6. Boundary-normal velocity differentials across the dryline, frontal segment, and distorted gust front at 2000 UTC. The computation assumes a $4 \mathrm{~m} \mathrm{~s}^{-1}$ wind from $170^{\circ}$ east of the dryline and a boundary orientation of $30^{\circ}$ north (south) of east (west). The velocity differential at each boundary is approximated by computing the vector difference of the boundary-normal winds across the boundary.

\begin{tabular}{lcc}
\hline \hline Boundary & $\begin{array}{c}\text { Wind vector } \\
\text { behind boundary }\end{array}$ & $\begin{array}{c}\text { Boundary-normal } \\
\text { velocity differential } \\
\left(\mathrm{m} \mathrm{s}^{-1}\right)\end{array}$ \\
\hline Dryline & $5 \mathrm{~m} \mathrm{~s}^{-1}$ from $280^{\circ}$ & -7.0 \\
Frontal segment & $7 \mathrm{~m} \mathrm{~s}^{-1}$ from $350^{\circ}$ & -10.3 \\
$\begin{array}{l}\text { Distorted storm } \\
\text { gust front }\end{array}$ & $7 \mathrm{~m} \mathrm{~s}^{-1}$ from $20^{\circ}$ & -8.3 \\
\hline
\end{tabular}

for each boundary are statistically significant for even large errors, this conclusion is robust.

Corfidi (1998) proposed that updraft regeneration near the cold front-dryline intersection could have been attributed to the localized low-level negative pressure perturbation associated with the prominent gravity wave moving southwestward over central Texas. However, while a mesolow was apparent throughout the morning near Waco, a localized low-level pressure minimum associated with the gravity wave, distinct from the expected storm-scale pressure minimum associated with ongoing deep convection, could not be identified. It is possible that localized ascent associated with the gravity wave, manifested as enhanced cloud cover, acted to decrease the convective inhibition, and perhaps aid the initial development of the storm complex, but the gravity wave was well south of the location of cell redevelopment and so it does not appear that it played a role in aiding systematic cell redevelopment.

The significant contribution from cell development along the cold front and dryline indicates that the preexisting boundaries were essential to the propagation of the storm complex. In fact, all but one of the longestlived cells whose origin could be identified developed on either the cold front or dryline. Moreover, every cell

TABLE 7. The maximum relative errors in the boundary-normal winds that are possible for the velocity differential values to be statistically significant at the $95 \%$ confidence interval.

\begin{tabular}{lc}
\hline \hline \multicolumn{1}{c}{ Boundaries } & $\begin{array}{c}\text { Max error } \\
\text { allowed for } \\
\text { statistically } \\
\text { significant } \\
\text { differences }\end{array}$ \\
\hline Dryline-frontal segment & $290 \%$ \\
Dryline-distorted storm gust front & $130 \%$ \\
Distorted storm gust front-frontal segment & $170 \%$ \\
\hline
\end{tabular}


found to develop on the gust front developed along the distorted portion only. As proposed above, the distorted gust front was strongly influenced by the horizontal shear across the cold front. Thus, even the cells forming along the storm-generated boundary, may have depended on the preexisting boundaries. It can therefore be argued that the preexisting boundaries were necessary for the maintenance and propagation of the storm complex. In fact, if the cold front were indeed responsible for the formation of the distorted gust front, the cold front alone would be implicated, either directly or indirectly, in the development of 11 of the 16 cells whose origin could be identified.

\section{c. Cell maintenance}

While the motion of the longest-lived cells was generally from west to east, many of the cells exhibited motions that deviated severely from the mean wind vector (Fig. 8). The departure of cell motion from the mean wind vector indicates that the propagation of these cells was controlled by quasi-continuous ${ }^{6}$ cell redevelopment. The possible mechanisms that may have been responsible for this redevelopment will be addressed in this section.

Cell development, whether discrete or quasicontinuous, requires access to a potentially unstable air mass and a forcing ("trigger") for cell initiation. As established in the previous section, cell initiation was triggered exclusively along the preexisting boundaries and distorted segment of the storm-generated gust front. By virtue of the consistent west-southwest-eastnortheast orientations that characterized each of these boundaries, cells moving partly in response to the mean wind (directed from the WSW) remained in close proximity to the potentially unstable air mass to the east. Moreover, because every cell developed southwest of the heaviest precipitation and coldest outflow air associated with the storm complex, nascent cells were not prematurely cut off from potentially unstable parcels. Therefore, the orientations of the preexisting boundaries of this event allowed cells to maintain access to the potentially unstable air mass to the east. This observation is consistent with Corfidi's proposition that storm persistence during this event "was dependent upon the generation of new updrafts at a rate and in a direction such that the cells were not undercut by their own outflow" (Corfidi 1998).

\footnotetext{
${ }^{6}$ Because of the radar sampling interval, it is possible that aliasing may have masked the discreteness of some cells. Therefore, the term "quasi-continuous" is used here to refer to cells that propagated continuously within the temporal resolution of the radar data.
}

Access to the potentially unstable air mass to the east does not, in and of itself, explain the observed deviate motion. One possible source of deviate motion in severe convection is the preferred updraft growth on the flanks attributable to the generation of vertical vorticity (the midlevel mesocyclone) through the tilting of the environmental horizontal vorticity associated with the vertical shear (Rotunno and Klemp 1982; Davies-Jones 1984; Rotunno and Klemp 1985). This mechanism for deviate motion will be referred to as supercell dynamics since the generation of a midlevel mesocyclone through this process is unique to supercells. Since midlevel rotation is typically strongest near the level maximum buoyancy (Rotunno and Klemp 1982), the search for midlevel mesocyclones should begin at this level (approximately $9 \mathrm{~km}$ AGL in this environment).

Midlevel mesocyclones were present in five of the eight longest-lived and well-sampled cells (Table 5). Midlevel mesocyclones were identified when the horizontal shear, computed using the maximum magnitudes of the inbound and outbound radial velocities across a given cell at an elevation of $9 \mathrm{~km}, 1$ ) equaled or exceeded $5 \times 10^{-3} \mathrm{~s}^{-1}$ for more than $15 \mathrm{~min}$ (the approximate convective time scale for this environment) and 2) exceeded $10 \times 10^{-3} \mathrm{~s}^{-1}$ during the $>15 \mathrm{~min}$ that it exceeded $5 \times 10^{-3} \mathrm{~s}^{-1}$. Results were fairly insensitive to the chosen thresholds, although a higher threshold for sustained horizontal shear $\left(6 \times 10^{-3} \mathrm{~s}^{-1}\right.$ instead of $5 \times 10^{-3} \mathrm{~s}^{-1}$ ) would have caused cell 1936A to be identified as nonmesocyclonic. Likewise, a lower threshold $\left(4 \times 10^{-3} \mathrm{~s}^{-1}\right)$ would have caused cell 2019A to be classified as mesocyclonic. No other cells possessed radar-detectable horizontal shear at $\sim 9 \mathrm{~km}$.

From the outset, it is apparent that the three longestlived and well-sampled cells that did not possess midlevel mesocyclones (2007A, 2013A, and 2019A) exemplified by far the least deviate motions (Fig. 8). This would suggest that mesocyclones had some relationship to the deviate motion of the remaining cells, but was it a causal relationship?

The presence of a midlevel mesocyclone is not an independent indicator of the existence of supercell dynamics and therefore may not confirm that supercell dynamics were driving deviate cell motion in this case. The advection and stretching of preexisting vertical vorticity into the midlevels could produce a midlevel mesocyclone (temporally coherent vertical vorticity highly correlated with vertical velocity) but would not yield cell maintenance/propagation through the mechanism described above and would not therefore yield deviate motion.

Unfortunately, data limitations in this case make it virtually impossible to identify the source of midlevel 
vertical vorticity for any of the cells. More importantly, the limited data do not allow for the identification of the role played by the observed updraft rotation on cell maintenance (this would require decomposition of the pressure field into the individual contributions to the nonhydrostatic vertical pressure gradient field). However, several analysis techniques have been administered to evaluate the likelihood that supercell dynamics were controlling cell motion and, if supercell dynamics were not the likely source of deviate motion, to identify other sources. These techniques are as follows:

- Compare the observed cell motion to predicted motion owing to supercell dynamics calculated using the Bunkers method (Bunkers et al. 2000),

- Compare the time of mesocyclone development to the onset of deviate motion,

- Account for other sources of deviate motion.

In this case, the most likely alternative cause of deviate cell motion is the cell redevelopment owing to forced ascent along preexisting or storm-generated airmass boundaries (e.g., Weaver 1979; Wade and Foote 1982; Weaver and Nelson 1982; Weaver et al. 1994). The possible mechanisms responsible for deviate motion are addressed by considering cells 2002A, 1936A, and 1851D. Cell 2002A was chosen because it was the parent cell of the Jarrell tornado; cell 1936A was chosen because it was the longest-lived cell (Table 5); and cell 1851D was chosen because it exhibited the most deviate motion (Fig. 8).

The source of the initial deviate motion of 2002A was likely boundary motion. Note from Fig. 21a that cell 2002A was initially located on or just ahead of the southwestward-moving distorted gust front. Cell motion to the east-southeast during this time reflected the combination of the gust front motion (to the south) and the mean flow (to the east-northeast). As evidenced in the cross section of radial velocity in Fig. 21a, no mesocyclone was present during this initial period of deviate motion. Moreover, no enhancement in rightward deviation occurred following mesocyclone formation, estimated to have occurred around 2013 UTC (see Fig. 21b). In fact, the leftward motion after 2013 UTC (Fig. 21b) and rightward motion after 2031 UTC (Fig. 21c,d) were nearly parallel to the gust front in these time periods suggesting that the cell was anchored to the boundary throughout its life and therefore owed its motion largely to the orientation and motion of this boundary. It should be noted, however, that the approximate cell motion, including rightward deviance, estimated using the Bunkers method applied to the two KGRK wind profiles, is in the direction of the observed motion (refer to the black arrows in the insets of Figs.
6 and 7) so any contributions to cell motion from supercell dynamics could have been masked by the boundary-driven deviate motion.

Cell 1936A provides another example of the apparent contribution to cell motion from boundary motion. Cell 1936A developed on the cold front, moved off of this boundary, and traveled with the mean flow until shortly after 1947 UTC when the cell was intercepted by the southwestward-moving distorted gust front (Fig. 22a). The cell continued to track northeastward along the distorted gust front (Fig. 22b) until it was intercepted by the southward-moving eastern segment of the gust front around 2002 UTC and began to move southeastward (Figs. 22c,d).

A mesocyclone was in place when this second segment of motion began and the motion predicted through the Bunkers method (refer to the motion estimates in Figs. 5-7) was nearly parallel to the motion. However, given that this rightward turn commenced $\sim 10$ min following mesocyclone formation but at the same time the cell was intercepted by the gust front suggests that this second segment of motion was likely driven by the southward motion of the gust front and not by supercell dynamics. The increase in SRH associated with this segment of motion yielded a significant increase in EHI and SCP values (Table 1) that would appear to be more favorable for supercells but the existing mesocyclone did not appear to intensify following the change in motion.

The south-southwestward motion of cell 1851D (see the cell track beginning at 1851 UTC in Fig. 8) was strikingly different from the motion of any other cell. It also represented the sole dominant cell in the "Lake Belton" storm. Recall that the Jarrell and Pedernales Valley storms contained multiple discrete cells that, owing to successive discrete cell redevelopment progressively farther southwest, led to back-building storm propagation. In marked contrast to these storms, the Lake Belton storm was almost exclusively composed of a single cell (1851D) propagating quasi-continuously to the southwest.

Despite the fact that the motion of cell 1851D consistently yielded one of the highest SRH values for each sounding (Table 1), its strongly deviate motion cannot be explained by any reasonable combination of the mean deep-layer flow and shear-induced (supercellular) deviate motion. Instead, cell 1851D appears to be another example in which boundary motion governed cell motion. Between 1804 and 1902 UTC, the frontal segment was observed to travel in a direction that was virtually parallel to the motion of 1851D (Fig. 23). (This southwestward motion of the frontal segment occurred because the intersection of the southward moving cold 

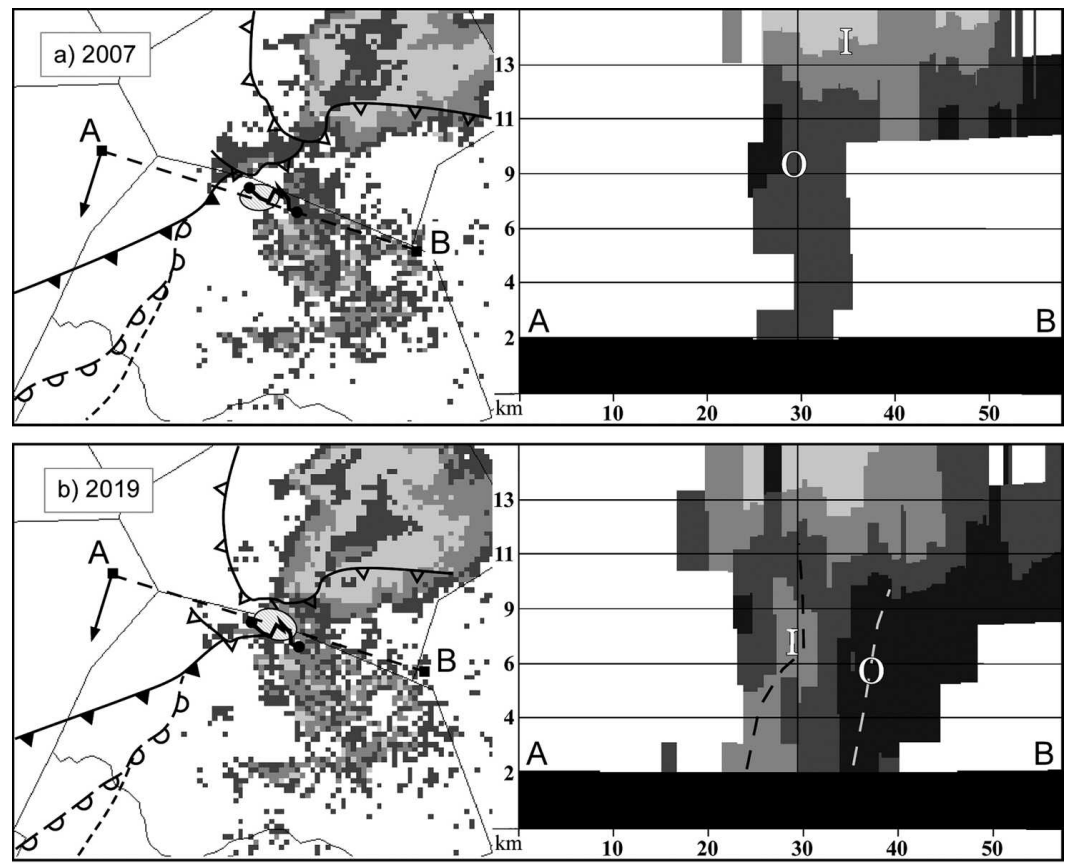

Radar Reflectivity (dBZ)
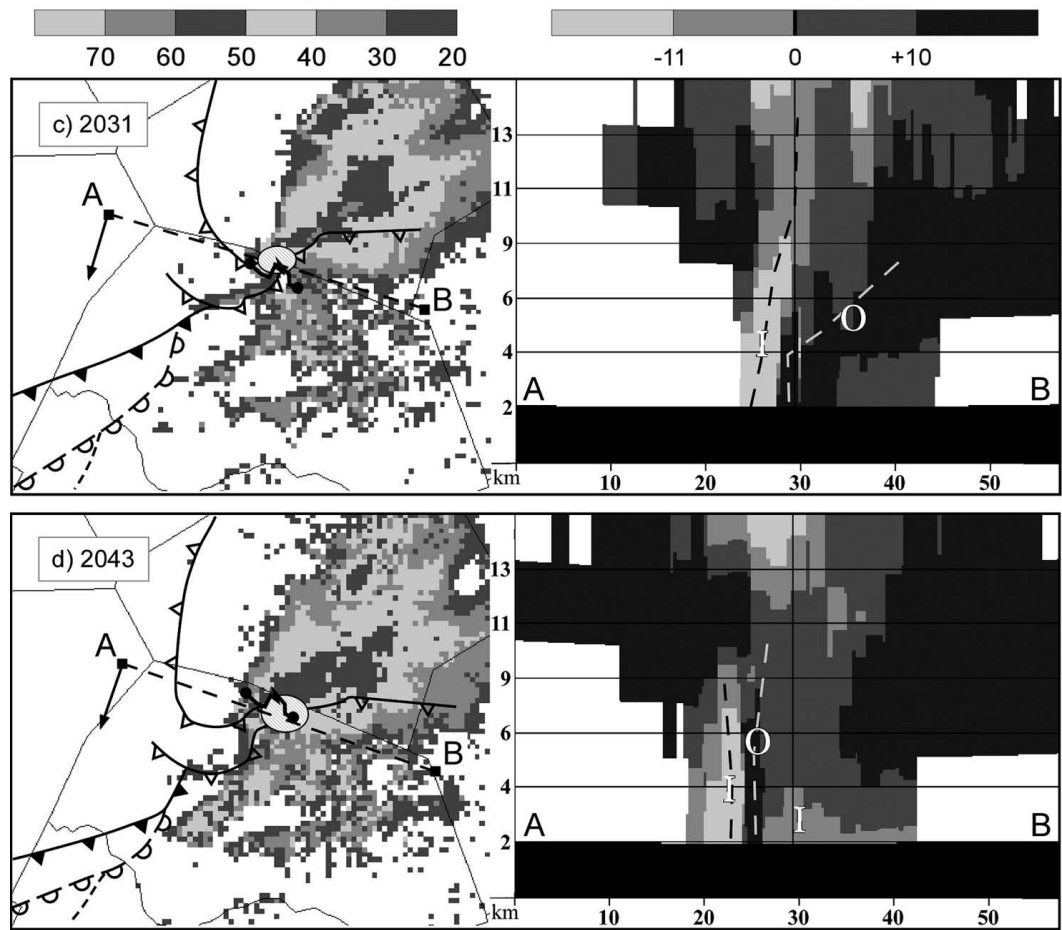

Fig. 21. Cell 2002A at (a) 2007, (b) 2019, (c) 2031, and (d) 2043 UTC. (left) The radar reflectivity (shaded every 10 from $20 \mathrm{dBZ}$ ) from the $0.5^{\circ}$ elevation scan of the KGRK radar, surface boundaries (as in Fig. 18), the track of cell 2002A (thick black curve with circles on its endpoints), the position of cell 2002A (the hatched oval), and the location of the (right) cross section (dashed line with squares on its endpoints; the arrow perpendicular to this line points in the direction of the radar used to build the cross section). (right) The radial velocity field in a cross section taken through cell 2002A. Regions of inbounds (outbounds) are denoted with an "I" ("O"). The dashed lines roughly correspond to the axes of inbounds and outbounds and the solid vertical line through the center of the image roughly corresponds to the cell center. The axes of the cross sections have units of $\mathrm{km}$. 

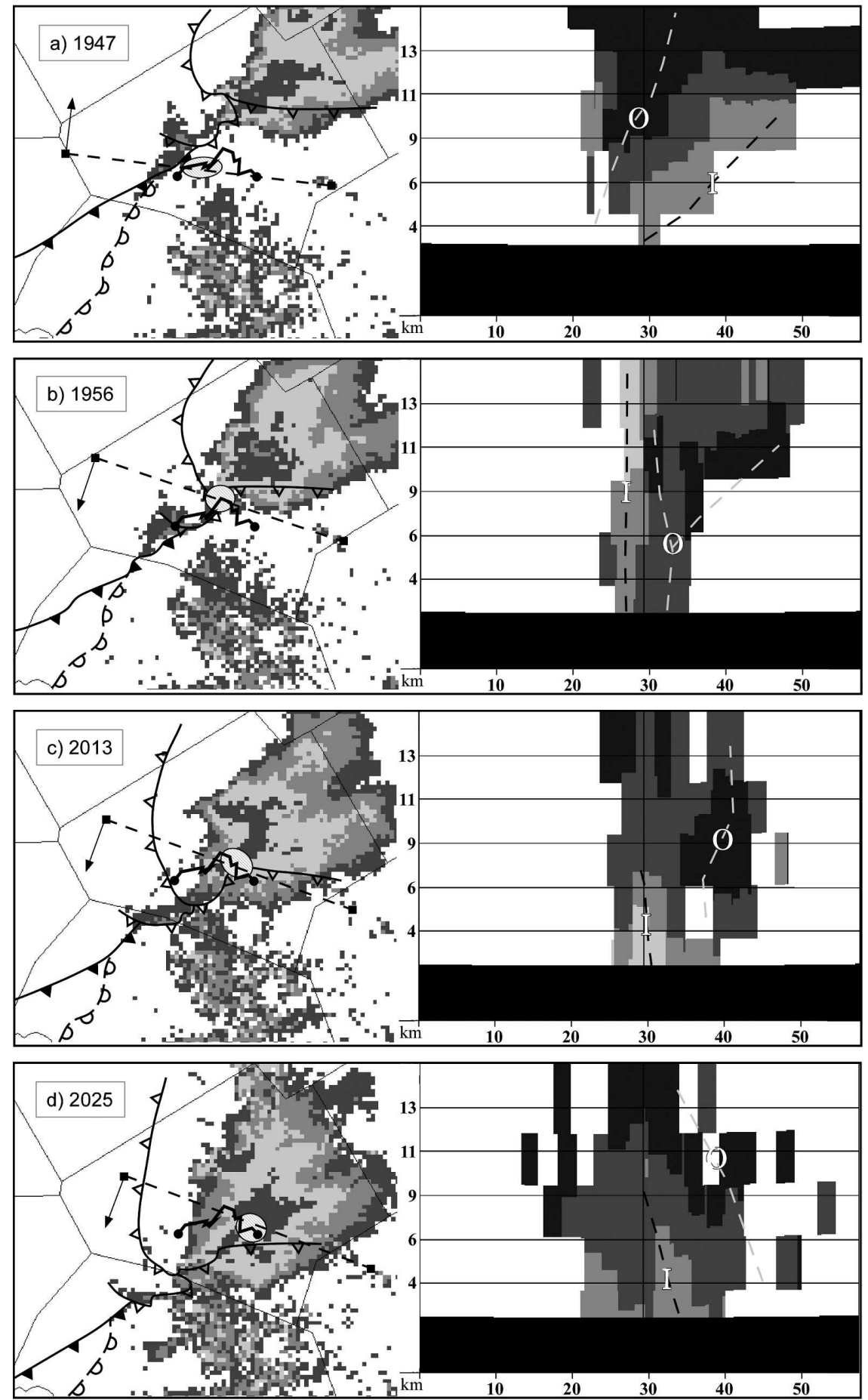

FIG. 22. Same as in Fig. 21 but for cell 1936A at (a) 1947, (b) 1956, (c) 2013, and (d) 2025 UTC.

front and generally stationary dryline traveled southwestward along the dryline.) Furthermore, the distorted gust front developed during this time and traveled to the southwest in tandem with the frontal segment. The similarity between the motions of the frontal segment, distorted gust front, and cell 1851D suggests that the maintenance/propagation of cell 1851D was driven by quasi-continuous forced ascent along the frontal segment and distorted gust front west-southwest of the cell. 


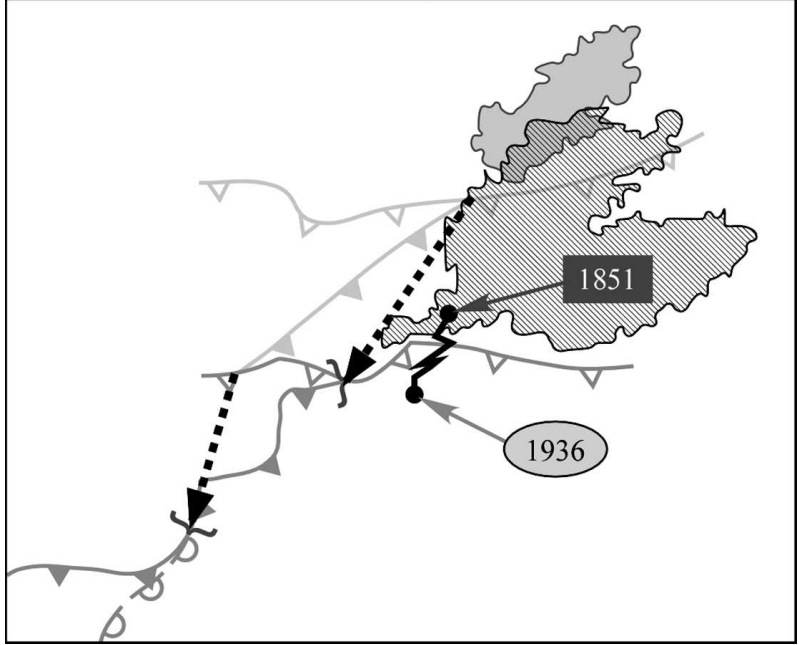

FIG. 23. Motion of cell 1851D relative to boundary motions. Reflectivities $\geq 30 \mathrm{~dB} Z$ from the $0.5^{\circ}$ elevation scan by KGRK at 1804 (1902) UTC are shaded (hatched). Boundaries (following the notation in Fig. 18) at 1804 (1902) UTC appear in light (dark) gray. For clarity, only the frontal segment portion of the cold front at 1804 UTC is included, whereas the frontal segment at 1902 UTC is the portion of the cold front between the gray brackets. The track of cell 1851D (between 1851 and 1936 UTC) is illustrated with the black curve with circles on its endpoints. (Because of data limitations, the position of cell 1851D prior to 1851 UTC could not be identified.) The two dotted arrows illustrate the motion of the frontal segment. They connect 1) the intersections of the frontal segment and the distorted gust front at 1804 and 1902 UTC and 2) the intersections of the fontal segment and the dryline at 1804 and 1902 UTC.

Consistent with the three examples presented above, analysis of the relationship between observed cell motion, expected cell motion, expected supercellular deviation, and boundary motion for the other longestlived and well-sampled cells (not shown) revealed little evidence that deviate motions generated through supercellular dynamics governed cell motions. However, as with cell 2002A, supercell dynamics could not be wholly discounted in some cases.

\section{Discussion}

\section{a. Previous cases of violent tornadoes in high-CAPE, low-shear environments}

Three well-documented events are often regarded as examples of violent tornadoes developing in highCAPE, low-shear environments: Ames, Iowa, 13 June 1976 (Brown and Knupp 1980); Grand Island, Nebraska, 3 June 1980 (Barlow 1983); and Plainfield, Illinois, 18 August 1990 (Korotky et al. 1993). Both the Ames and Plainfield tornadoes produced F5-rated damage while the most destructive tornado of the
Grand Island event produced F4 damage. Using representative soundings composited by the three sets of authors listed above, the 1D metrics of section 2 were used to characterize these environments. Results are summarized in Table 8 and reflected in Figs. 10-16.

While the values of $1 \mathrm{D}$ metrics for the three cases exceed the corresponding mean for the 27 May 1997 event, it is clear that, like this event, the Ames environment was at best marginally favorable for supercells and unfavorable for significant tornadoes. Furthermore, based on the soundings synthesized post facto by Barlow (1983) and Korotky et al. (1993) for the Grand Island and Plainfield tornadoes, respectively, both of these events occurred in environments that were clearly supportive of supercells and significant tornadoes.

\section{b. Back building}

While the central Texas event was clearly not a squall line during the period considered for this work, it is worth placing this environment in context with the climatologies of back-building squall lines documented in the literature. Bluestein and Jain (1985) determined that severe, back-building squall lines were supported in environments with strong vertical shear. They found that the average value for the bulk Richardson number shear $\left(\mathrm{BRI}_{\text {shear }}\right)$ associated with severe back-building squall lines was 90.6. The bulk Richardson number shear values for this event were well below this value: The values for the Calvert, KGRK 1932 UTC, and KGRK 2001 UTC wind profiles were 9.4, 34.3, and 30.3. In fact, these values are more in line with the mean value of bulk Richardson shear (29) found for nonsevere back-building squall-line environments (Bluestein et al. 1987).

The mechanisms responsible for the back building of squall lines remain a source of speculation. Bluestein and Jain (1985) suggest that the back-building behavior in squall lines may be a consequence of a zonal gradient in the strength of the low-level inversion/cap: a progressively stronger cap southward along the initiating boundary would require additional destabilization of the atmosphere for convective initiation, thus the time of convective initiation would be later to the south. Newton (1963) argued that the southward development of back-building squall lines results when an airmass boundary intercepts an "instability tongue" characterized by a meridional gradient in instability. In this model, the southernmost extent of the squall line develops progressively farther south as new cell development occurs at the point where the advancing cold front first encounters the instability tongue (Fig. 24).

For the central Texas event, data limitations make identifying a zonal gradient in cap strength difficult. 
TABLE 8. Summary of 1D metrics used to characterize the environments associated with the Ames, Grand Island, and Plainfield events.

\begin{tabular}{|c|c|c|c|c|c|c|c|c|}
\hline Case & $\begin{array}{l}\text { CAPE } \\
\left(\mathrm{J} \mathrm{kg}^{-1}\right)\end{array}$ & $\begin{array}{l}\mathrm{SRH}_{0-1} \\
\left(\mathrm{~m}^{2} \mathrm{~s}^{-2}\right)\end{array}$ & $\begin{array}{l}\mathrm{SRH}_{0-3} \\
\left(\mathrm{~m}^{2} \mathrm{~s}^{-2}\right)\end{array}$ & $\begin{array}{l}\Delta V_{0-6} \\
\left(\mathrm{~m} \mathrm{~s}^{-1}\right)\end{array}$ & $\mathrm{EHI}_{0-1}$ & SCP & $\begin{array}{l}\mathrm{LCL} \\
(\mathrm{m})\end{array}$ & STP \\
\hline $\begin{array}{l}\text { Plainfield, IL } \\
28 \text { Aug } 1990\end{array}$ & 6980 & 165 & 150 & 13.6 & 7.2 & 7.8 & 985 & 5.3 \\
\hline $\begin{array}{l}\text { Grand Island, NE } \\
3 \text { Jun } 1980\end{array}$ & 4886 & 115 & 272 & 19.6 & 3.5 & 20.2 & 1100 & 3.4 \\
\hline $\begin{array}{l}\text { Ames, IA } \\
13 \text { Jun } 1976\end{array}$ & 3800 & 29 & 35 & 18.0 & 0.69 & 1.4 & 1000 & 0.7 \\
\hline
\end{tabular}

However, the role played by the multiple boundaries of this event suggests an alternative explanation that resembles Newton's conceptual model for back-building propagation/maintenance. While Newton's proposition did not specifically treat the behavior of multiple boundaries, his model can be easily extended to the interaction between the cold front and dryline that resulted in the back-building maintenance/propagation of this case. In this event, the dryline demarcated the western edge of the instability tongue. New cell development occurred where the southward moving cold front first overtook the dryline and penetrated into the most unstable air (i.e., the instability tongue) to the east. The propagation of the storm followed the southward advancement of this intersection of the cold front and

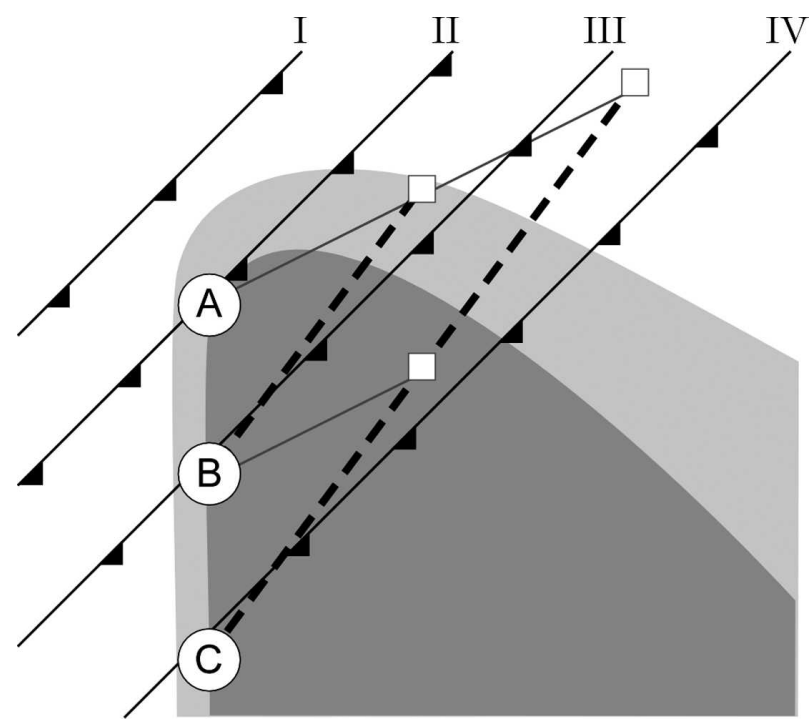

FIG. 24. Cartoon illustrating the conceptual model of back building proposed by Newton (1963) and adapted from his Fig. 9. Successive positions of a cold front (barbed lines) advancing into an instability tongue (shading; best interpreted as low-level $\theta_{\mathrm{e}}$ ). Cell development is indicated with circled letters and successive positions of these cells are indicated with squares. The thick dashed lines represent the positions of the squall line made of these cells. dryline (the frontal segment). In this way, the cold front and dryline resembled two ends of a zipper (Fig. 25) that, when closed toward the southwest, resulted in the back-building of the storm complex.

Recall that cell development did not occur along the portion of the cold front west of the dryline. Neither was cell development observed along the dryline until 2007 UTC - $2 \mathrm{~h}$ after the development of the Lake Belton storm and more than $1 \mathrm{~h}$ after the development of the Jarrell storm. In fact, no cells that developed on the dryline contributed to either the Jarrell or Lake Belton storms. And while the contribution to back building from cell development along the storm-generated distorted gust front cannot be neglected, it was the "zippering" of the cold front and dryline that appeared to

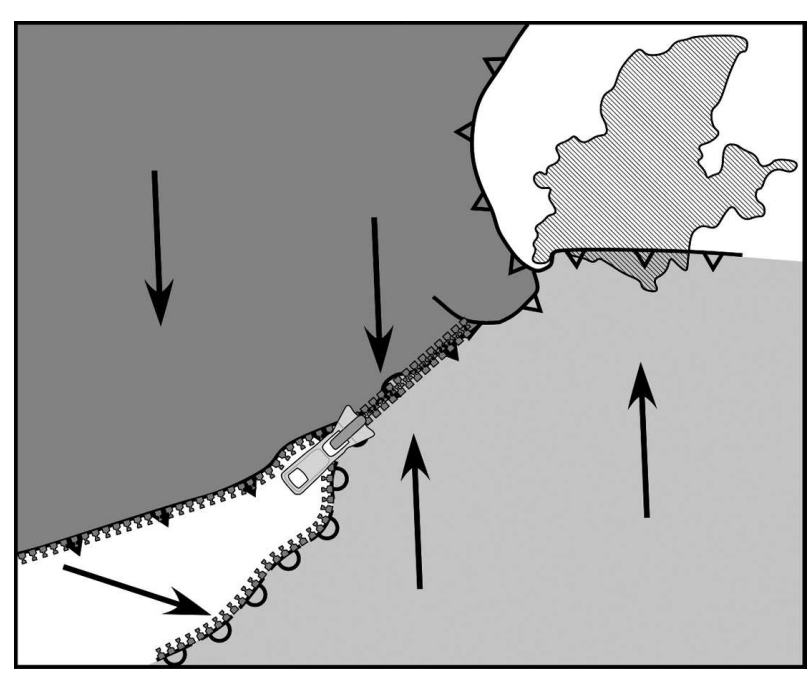

FIG. 25. Cartoon illustrating the zippering of the cold front and dryline that was essential for the back building of the storm complex. Data from 1956 were used for the position of the boundaries (notation as in Fig. 18) and reflectivity (values greater than 40 $\mathrm{dB} Z$ are hatched). Arrows indicate the direction of the flow in the various air masses. Light shading represents the most unstable air mass to the east while the dark shading represents the air mass that was generally required to be in contact with the eastern air mass for cell redevelopment. 
be essential for the back-building of the storm complex in this event.

Although the extreme values of CAPE make this case rather unique, the "zippering" of the cold front and dryline and ensuing back-building behavior have been observed in other cases. The 10-11 April 1979 Severe Environmental Storms and Mesoscale Experiment (SESAME) case simulated by Ross (1987) and Hemler et al. (1991) was characterized by a backbuilding squall line in northwest Texas. Although the dryline in place during this event initiated deep convection, back building commenced when a cold front caught up with the dryline. The portion of the cold front in contact with the air to the east was found to have larger convergence than elsewhere along the dryline.

\section{Summary}

This article reported findings from analysis of the multiple-tornado event in central Texas on 27 May 1997. The primary objectives were to document the prestorm environment and to examine the backbuilding propagation/maintenance of the storm complex, focusing on the role played by preexisting airmass boundaries. Analysis was carried out using a broad suite of synoptic and subsynoptic data but focused on the WSR-88D data from the KGRK, KEWX, and KFWS radars. The primary conclusions from this analysis are as follows:

- The environment associated with this event was characterized by CAPE in excess of $6500 \mathrm{~J} \mathrm{~kg}^{-1}$.

- One-dimensional metrics calculated from wind profiles crafted from the available data for this event along with observed cell motions revealed that while some of the wind profile-cell motion combinations yielded conditions that were similar to the conditions typically associated with supercells, most combinations more closely resembled environments associated with nonsupercells. Thus, this environment could best be classified as only marginally favorable for supercells.

- One-dimensional metrics also revealed that the environment of this event was unfavorable for significant tornadoes.

- Comparison of this environment to other cases of back-building storms revealed that the observed wind shear was more in line with the vertical shear typically associated with nonsevere back-building storms.

- Discrete cell redevelopment was found to control the back-building propagation/maintenance of the Jarrell and Pedernales Valley storms. Cells in these storms were found to develop exclusively along the frontal segment (the small segment of the cold front that had overtaken the dryline), the distorted storm-generated gust front (the portion of the gust front south/west of the gust front cusp), and the dryline near its intersection with the NCMC.

- Although the configuration of the distorted gust front resembled the configuration of the rear-flank gust front of an archetypical supercell, it was proposed that a significant, if not primary, cause of the gust front distortion was the horizontal shear across the cold front, which allowed the storm-generated outflow to travel more rapidly to the south on the west side of the cold front than on the east side. This distinction is not merely an academic one since this conclusion implicates the cold front, either directly or indirectly, in the development of 11 of the 16 cells whose origin could be identified. Moreover, this conclusion indicates that every observed cell whose origin could be identified was dependent on the preexisting boundaries and, therefore, that preexisting boundaries were necessary for the maintenance and propagation of the storm complex.

- The apparent dependence of cell development along the dryline on its interaction with the NCMC suggests that the dryline alone was incapable of initiating new cells. Analysis of the wind fields across the frontal segment, distorted gust front, and dryline revealed that the convergence was likely larger along the frontal segment and distorted gust front.

- The maintenance and longevity of individual cells was likely aided by the west-southwest-eastnortheast orientations of the three initiating boundaries. Cells developing on these boundaries and traveling partly in response to the mean wind (directed from the west-southwest) remained in close proximity to the potentially unstable air mass to the east. Moreover, because every cell developed southwest of the heaviest precipitation and coldest outflow air associated with the storm complex, nascent cells were not prematurely cut off from potentially unstable parcels.

- Unlike the Jarrell and Pedernales Valley storms, the back building of the Lake Belton storm was controlled by the quasi-continuous redevelopment of a single cell. This cell appeared to develop quasicontinuously to the south through forced ascent along the southwestward moving frontal segment and distorted gust front.

- The southwestward motion of the frontal segment ultimately governed the back-building propagation/ maintenance of all three storms. The frontal segment represented the location where the cold front and dryline were "zippered" together; that is, where the 
cold front first overtook the dryline and penetrated into the most unstable air to the east.

- Midlevel mesocyclones were found in five of the eight longest-lived and well-sampled cells. However, analysis of the relationship between observed cell motion, expected cell motion, expected supercellular deviation, and boundary motion for the longest-lived and well-sampled cells revealed little evidence that deviate motions generated through supercellular dynamics governed cell motions. Instead, it was apparent that boundary motions largely controlled cell motions.

As documented above, the (1D) environment of this event was unfavorable for significant tornadoes and yet it still supported six tornadoes that produced $\geq \mathrm{F} 2$ damage. The purpose of the second article in this series is to examine the spatiotemporal interrelationships between the observed tornadoes, preexisting and stormgenerated boundaries, antecedent low-level mesocyclones, convective cells, and midlevel mesocyclones.

Acknowledgments. We are indebted to M. Gilmore and L. Curtis for their thorough review of an early draft of this manuscript. We are grateful for the careful critiques of several anonymous reviewers that greatly improved the quality of this paper. We thank M. Ramamurthy, R. Rauber, L. Wicker, and B. Jewett for their insightful discussions regarding this work. We would also like to thank M. Magsig for providing the level-III KGRK data, S. Corfidi for graciously providing his subjective mesoanalyses of the 27 May 1997 event, and M. Biggerstaff and the volunteers in the TEXACAL experiment for acquiring and providing the Calvert sounding. Thanks also go to M. Weisman for his helpful responses to A. Houston's queries. We are also indebted to D. Wojtowicz whose unfaltering computer support was integral to the analysis of this case. Funding for this work was provided through NSF Grants ATM-9986672 and ATM-0449753.

\section{REFERENCES}

Barlow, W., 1983: Analysis of the Grand Island tornadoes of June 3, 1980. Preprints, 13th Conf. on Severe Local Storms, Tulsa, OK, Amer. Meteor. Soc., 277-280.

Beebe, R. G., 1958: Tornado proximity soundings. Bull. Amer. Meteor. Soc., 39, 195-201.

Biggerstaff, M. I., and Coauthors, 1997: The Texas A\&M University convection and lightning experiment-TEXACAL 97. Preprints, 28th Conf. on Radar Meteorology, Austin, TX, Amer. Meteor. Soc., 588-589.

Bluestein, H. B., and M. H. Jain, 1985: Formation of mesoscale lines of precipitation: Severe squall lines in Oklahoma during the spring. J. Atmos. Sci., 42, 1711-1732.

_, G. T. Marx, and M. H. Jain, 1987: Formation of mesoscale lines of precipitation: Nonsevere squall lines in Oklahoma during the spring. Mon. Wea. Rev., 115, 2719-2727.

Brooks, H. E., C. A. Doswell III, and R. B. Wilhelmson, 1994: The role of midtropospheric winds in the evolution and maintenance of low-level mesocyclones. Mon. Wea. Rev., 122, $126-136$.

Brown, J. M., and K. R. Knupp, 1980: The Iowa cyclonicanticyclonic tornado pair and its parent thunderstorm. Mon. Wea. Rev., 108, 1626-1646.

Browning, K. A., 1977: The Structure and Mechanisms of Hailstorms. Meteor. Monogr., No. 16, Amer. Meteor. Soc., 1-43.

Bunkers, M. J., B. A. Klimowski, J. W. Zeitler, R. L. Thompson, and M. L. Weisman, 2000: Predicting supercell motion using a new hodograph technique. Wea. Forecasting, 15, 61-79.

Corfidi, S. F., 1998: Some thoughts on the role mesoscale features played in the 27 May 1997 central Texas tornado outbreak. Preprints, 19th Conf. on Severe Local Storms, Minneapolis, MN, Amer. Meteor. Soc., 177-180.

Davies-Jones, R. P., 1984: Streamwise vorticity: The origin of updraft rotation in supercell storms. J. Atmos. Sci., 41, 29913006.

— D. W. Burgess, and M. P. Foster, 1990: Test of helicity as a tornado forecast parameter. Preprints, 16th Conf. on Severe Local Storms, Kananaskis Park, AB, Canada, Amer. Meteor. Soc, 588-592.

Fovell, R. G., and Y. Ogura, 1989: Effect of vertical wind shear on numerically simulated multicell storm structure. J. Atmos. Sci., 46, 3144-3176.

Hart, J. A., and W. Korotky, 1991: The SHARP workstation v1.50 users guide. NOAA/National Weather Service, 30 pp. [Available from NWS Eastern Region Headquarters, 630 Johnson Ave., Bohemia, NY 11716.]

Hemler, R. S., F. B. Lipps, and B. B. Ross, 1991: A simulation of a squall line using a nonhydrostatic cloud model with $5-\mathrm{km}$ horizontal grid. Mon. Wea. Rev., 119, 3012-3033.

Houston, A. L., and R. B. Wilhelmson, 2007: Observational analysis of the 27 May 1997 Central Texas tornadic event. Part II: Tornadoes. Mon. Wea. Rev., 135, 727-735.

Klemp, J. B., R. B. Wilhelmson, and P. S. Ray, 1981: Observed and numerically simulated structure of a mature supercell thunderstorm. J. Atmos. Sci., 38, 1558-1580.

Korotky, W., R. W. Przybylinski, and J. A. Hart, 1993: The Plainfield, Illinois tornado of August 28, 1990: The evolution of synoptic and mesoscale environments. The Tornado: Its Structure, Dynamics, Prediction, and Hazards, C. R. Church, Ed., Vol. 79, Amer. Geophys. Union, 611-624.

Lemon, L. R., and C. A. Doswell III, 1979: Severe thunderstorm evolution and mesocyclone structure as related to tornadogenesis. Mon. Wea. Rev., 107, 1184-1197.

Magsig, M. A., D. W. Burgess, and R. R. Lee, 1998a: Multiple boundary evolution and tornadogenesis associated with the Jarrell, Texas events. Preprints, 19th Conf. on Severe Local Storms, Minneapolis, MN, Amer. Meteor. Soc., 186-189.

_ J. G. LaDue, D. W. Burgess, and R. R. Lee, 1998b: A radar and satellite analysis of tornadic storm updraft evolution on 27 May 1997. Preprints, 16th Conf. on Weather Analysis and Forecasting, Phoenix, AZ, Amer. Meteor. Soc., 320-322.

NCDC, 1997: Storm Data. Vol. 39, No. 5, 229 pp.

Newton, C. W., 1963: Dynamics of severe convective storms. Severe Local Storms, Meteor. Monogr., No. 27, Amer. Meteor. Soc., 33-58.

NOAA, 1998: The central Texas tornadoes of May 27, 1997. Service Assessment, 99 pp. [Available from National Weather 
Service, 1325 East-West Highway, Silver Spring, MD 209103283.]

NSSL, 2000: WATADS (WSR-88D Algorithm Testing and Display System) 2000: Reference guide for version 10.2. NSSL, 200 pp. [Available from Storm Scale Applications Division, National Severe Storms Laboratory, 1313 Halley Circle, Norman, OK 73069.]

Rasmussen, E. N., 2003: Refined supercell and tornado forecast parameters. Wea. Forecasting, 18, 530-535.

—_, and D. O. Blanchard, 1998: A baseline climatology of sounding-derived supercell and tornado forecast parameters. Wea. Forecasting, 13, 1148-1164.

Ross, B. B., 1987: The role of low-level convergence and latent heating in a simulation of observed squall line formation. Mon. Wea. Rev., 115, 2298-2321.

Rotunno, R., and J. B. Klemp, 1982: The influence of the shearinduced pressure gradient on thunderstorm motion. Mon. Wea. Rev., 110, 136-151.

— lated supercell thunderstorms. J. Atmos. Sci., 42, 271-292.

Sanders, F., 2005: Real front or baroclinic trough? Wea. Forecasting, 20, 647-651.

Segal, M., and R. W. Arritt, 1992: Nonclassical mesoscale circulations caused by surface sensible heat-flux gradients. Bull. Amer. Meteor. Soc., 73, 1593-1604.
Thompson, R. L., R. Edwards, J. A. Hart, K. L. Elmore, and P. M. Markowski, 2003: Close proximity soundings within supercell environments obtained from the Rapid Update Cycle. Wea. Forecasting, 18, 1243-1261.

Wade, C. G., and G. B. Foote, 1982: The 22 July 1976 case study: Low-level airflow and mesoscale influences. Hailstorms of the Central High Plains, C. A. Knight and P. Squires, Eds., Vol. 2, Colorado Associated University Press, 115-130.

Weaver, J. F., 1979: Storm motion as related to boundary-layer convergence. Mon. Wea. Rev., 107, 612-619.

— , and S. P. Nelson, 1982: Multiscale aspects of thunderstorm gust fronts and their effects on subsequent storm development. Mon. Wea. Rev., 110, 707-718.

— W. Purdom, and E. J. Szoke, 1994: Some mesoscale aspects of the 6 June 1990 Limon, Colorado, tornado case. Wea. Forecasting, 9, 45-61.

Weisman, M. L., M. S. Gilmore, and L. J. Wicker, 1998: The impact of convective storms on their local environment: What is an appropriate ambient sounding? Preprints, 19th Conf. on Severe Local Storms, Minneapolis, MN, Amer. Meteor. Soc., 238-241.

Wilson, J. W., and W. E. Schreiber, 1986: Initiation of convective storms at radar-observed boundary-layer convergence lines. Mon. Wea. Rev., 114, 2516-2536. 